Article

\title{
Platinum-Group Minerals and Other Accessory Phases in Chromite Deposits of the Alapaevsk Ophiolite, Central Urals, Russia
}

\author{
Federica Zaccarini ${ }^{1, *}$, Evgeny Pushkarev ${ }^{2}$, Giorgio Garuti ${ }^{1}$ and Igor Kazakov ${ }^{3}$ \\ 1 Department of Applied Geosciences and Geophysics, University of Leoben, Peter Tunner Str.5, \\ A 8700 Leoben, Austria; giorgio.garuti1945@gmail.com \\ 2 Institute of Geology and Geochemistry, Ural Division of Russian Academy of Sciences, Str. Pochtovy per. 7, \\ 620151 Ekaterinburg, Russia; pushkarev@igg.uran.ru \\ 3 Joint Stock Company Ural Geological Survey Expedition, str. Vaynera 55, 620014 Ekaterinburg, Russia; \\ kazakov@ugse.ru \\ * Correspondence: federica.zaccarini@unileoben.ac.at; Tel.: +43-3842-402-6218
}

Academic Editor: Maria Economou-Eliopoulos

Received: 1 August 2016; Accepted: 10 October 2016; Published: 19 October 2016

\begin{abstract}
An electron microprobe study has been carried out on platinum-group minerals, accessory phases, and chromite in several chromite deposits of the Alapaevsk ophiolite (Central Urals, Russia) namely the Bakanov Kluch, Kurmanovskoe, Lesnoe, 3-d Podyony Rudnik, Bol'shaya Kruglyshka, and Krest deposits. These deposits occur in partially to totally serpentinized peridotites. The microprobe data shows that the chromite composition varies from Cr-rich to Al-rich. Tiny platinum-group minerals (PGM), 1-10 $\mu \mathrm{m}$ in size, have been found in the chromitites. The most abundant PGM is laurite, accompanied by minor cuproiridsite and alloys in the system Os-Ir-Ru. A small grain (about $20 \mu \mathrm{m}$ ) was found in the interstitial serpentine of the Bakanov Kluch chromitite, and its calculated stoichiometry corresponds to $(\mathrm{Ni}, \mathrm{Fe})_{5} \mathrm{P}$. Olivine, occurring in the silicate matrix or included in fresh chromite, has a mantle-compatible composition in terms of major and minor elements. Several inclusions of amphibole, Na-rich phlogopite, and clinopyroxene have been identified. The bimodal $\mathrm{Cr}-\mathrm{Al}$ composition of chromite probably corresponds to a vertical distribution in the ophiolite sequence, implying formation of $\mathrm{Cr}$-rich chromitites in the deep mantle, and Al-rich chromitites close to the Moho-transition zone, in a supra-subduction setting. The presence of abundant hydrous silicate inclusions, such as amphibole and phlogopite, suggests that the Alapaevsk chromitites crystallized as a result of the interaction between a melt enriched in fluids and peridotites. Laurite and cuproiridsite are considered to be magmatic in origin, i.e., entrapped as solid phases during the crystallization of chromite at high temperatures. The sulfur fugacity was relatively high to allow the precipitation of Ir-bearing sulfides, but below the Os-OsS 2 buffer. The alloys in the system Os-Ir-Ru are classified as secondary PGM, i.e., formed at low temperature during the serpentinization process. The $(\mathrm{Ni}, \mathrm{Fe})_{5} \mathrm{P}$ phase is the first occurrence of a Ni-phosphide in terrestrial samples. Its composition indicates that it may be a new mineral. However, the small size has, so far, prevented a crystallographic study to support this conclusion.
\end{abstract}

Keywords: chromitite; platinum group minerals; silicate inclusions; Ni-phosphide; ophiolite; Alapaevsk; Urals; Russia

\section{Introduction}

The Uralian orogenic belt, which extends $2500 \mathrm{~km}$ from the Polar Urals to the Aral Lake, is considered the boundary between Europe and Asia. The belt formed because of the collision between the East European continental platform to the west and the Asian plate to the east. The process of 
collision started in the Paleozoic and ended in the early Jurassic. This tectonic event brought to the surface many mafic-ultramafic complexes (Figure 1) occurring in both the east and west slopes of the Ural Mountains [1].

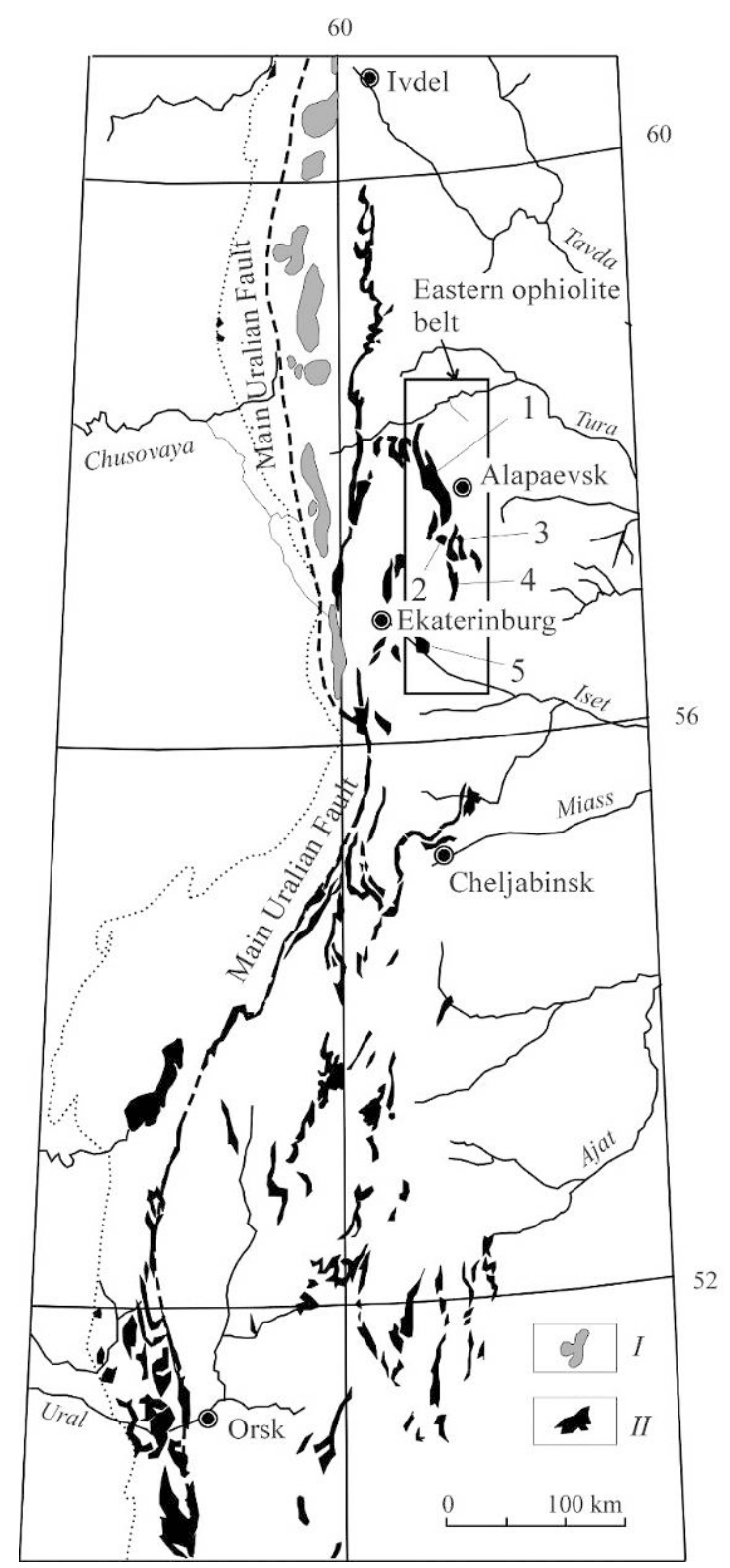

Figure 1. The distribution of mafic-ultramafic complexes in the Urals (excluding Circumpolar and Polar sectors of the Urals) (simplified after [2]). I-dunite-clinopyroxenite-gabbro massifs of the Ural Platinum Belt; II-ophiolite complexes. Eastern ophiolite belt: 1-Alapaevsk massif; 2-Ostaninsky massif; 3-Rezhevskoy massif; 4-Bazhenovsky massif; 5-Kluchevskoy massif. Rectangle shows the northern end of the Eastern ophiolite belt where the Alapaevsk massif is located.

The mafic-ultramafic complexes can be grouped into three main types: (1) harzburgite-dunitevolcanic associations considered to be sections through the upper mantle-crust transition of Palaeozoic ophiolites; (2) concentrically zoned dunite-clinopyroxenite-gabbro intrusions derived from deep magmatic activity in island arc (Ural-Alaskan type) complexes and (3) lherzolite-harzburgite blocks representing weakly depleted mantle derived rocks that formed the floor during overthrusting of huge allochthonous or huge ophiolite massifs that were true oceanic crust [2-6]. 
Since the beginning of the last century, the Urals have become known for their importance in the exploration and recovery of chromium. Chromite deposits containing more than $100 \mathrm{Mt}$ of ore reserve have been discovered in the Kempirsai massif of Kazakhstan and in the complexes of Voykar Sininsky and Ray-Iz located in the Polar Urals, Russia ([6] and references therein). The giant chromite ore bodies of the Urals occur exclusively in the peridotite of subduction-related ophiolites [7]. However, chromitites varying in size from potential ore deposits down to sub-economic concentrations of chromite also occur, associated with various types of Uralian ophiolites ([6] and references therein). Ophiolitic chromitites in general, as well as those occurring in the Urals, show a wide compositional range from Al-rich to $\mathrm{Cr}$-rich chromite. This compositional variation is a function of many factors such as the composition of the parental magmas, the nature of their mantle sources, the vertical distribution from the deeper part of the upper mantle to the mantle-crust transition zone, and different geodynamic settings. It is known that the ophiolitic chromitites may contain sub-economic concentrations of platinum-group elements (PGE), with particular enrichment of IPGE (Os + Ir + Ru) over the PPGE $(\mathrm{Rh}+\mathrm{Pt}+\mathrm{Pd})$. The mineralogical expression of the PGE content is platinum-group minerals (PGM) that form tiny phases, generally less than $10 \mu \mathrm{m}$ in size and unevenly disseminated in the chromitite. In this contribution we present the results of a new, detailed study of chromite composition and the first data on accessory minerals such as silicates, PGM, and a rare NiFeP compound found in certain chromite deposits that occur in the Alapaevsk ophiolite, located in the Central Urals. We use this data to model the tectonic setting and genesis of the chromitites and their host ophiolite and to better understand the mechanisms of the precipitation of PGM and other rare accessory phases.

\section{Geological Background of the Alapaevsk Ophiolite}

The northern segment of the Eastern Uralian ophiolite belt extends along the 61th meridian for about $200 \mathrm{~km}$ and comprises the following ophiolite massifs, listed from north to south: Alapaevsk, Ostaninsky, Rezhevskoy, Bazhenovsky, Kluchevskoy (Figure 1), as well as other smaller bodies. The Alapaevsk [8] and Kluchevskoy [9] massifs contain economic and sub-economic chromite deposits. The Bazhenovsky massif hosts one of the largest asbestos deposits in the world, containing about 6 billion tons of chrysotile asbestos, and from the Rezhevskoy massif a few economic nickel deposits in the weathering crust have been mined [10,11]. The Alapaevsk ophiolite massif is one of the largest in the Eastern belt, and is located about $150 \mathrm{~km}$ northeast from Ekaterinburg and approximately $15 \mathrm{~km}$ west of the city of Alapaevsk (Figure 1). The massif consists of a plate-like body $55 \mathrm{~km}$ long and $6-13 \mathrm{~km}$ wide, covering an area of about $500 \mathrm{~km}^{2}$. The Alapaevsk complex is tectonically in contact with an island arc sequence composed of metavolcanics and sediments of Devonian-Carboniferous age (Figure 2). The sequence overlaps the Alapaevsk ophiolite as a tectonic nappe in the central and southern parts. The eastern and western tectonic contacts with the country rocks dip to the center of the massif. Talc-carbonate metasomatic rocks have been recognized along the contacts [10]. The Alapaevsk ophiolite consists mainly of peridotites and gabbro. Geophysical data have shown that the thickness of peridotites varies from 0.5 up to $2 \mathrm{~km}$. Harzburgite and small amounts of lherzolite, dunite and chromitite (Figure 2) have been described in the Alapaevsk complex.

The degree of serpentinization of the Alapaevsk ophiolite varies widely, but in general it is very high and peridotites are often completely transformed to serpentinite. Wehrlite and pyroxenite are rare and they are mostly found in the gabbro intrusion, cutting the peridotite in the northern apex of the massif (Figure 2). Sometimes they form small veins in peridotite. On the basis of the concordant U-Pb age of zircons found in the chromitites, the age of the Alapaevsk ophiolite massif is $588 \pm 16 \mathrm{Ma}$ [12]. The gabbro has a similar Sm-Nd age of $579 \pm 42 \mathrm{Ma}$ [12]. An Upper Paleozoic collisional granite massif (Figure 2) intrudes the Proterozoic metamorphic rocks westward of the Alapaevsk massif. Close to the contact with the ultramafic rocks, the granite intrusion forms metasomatic phlogopite rocks that contain beryl and emerald $[10,13]$. Smaller Upper Paleozoic granite intrusions cut the peridotite along its western contact (Figure 2). Several amphibole-asbestos deposits occur in the central and eastern part of the Alapaevsk massif. They have been intensively mined in the past $[10,11]$. 


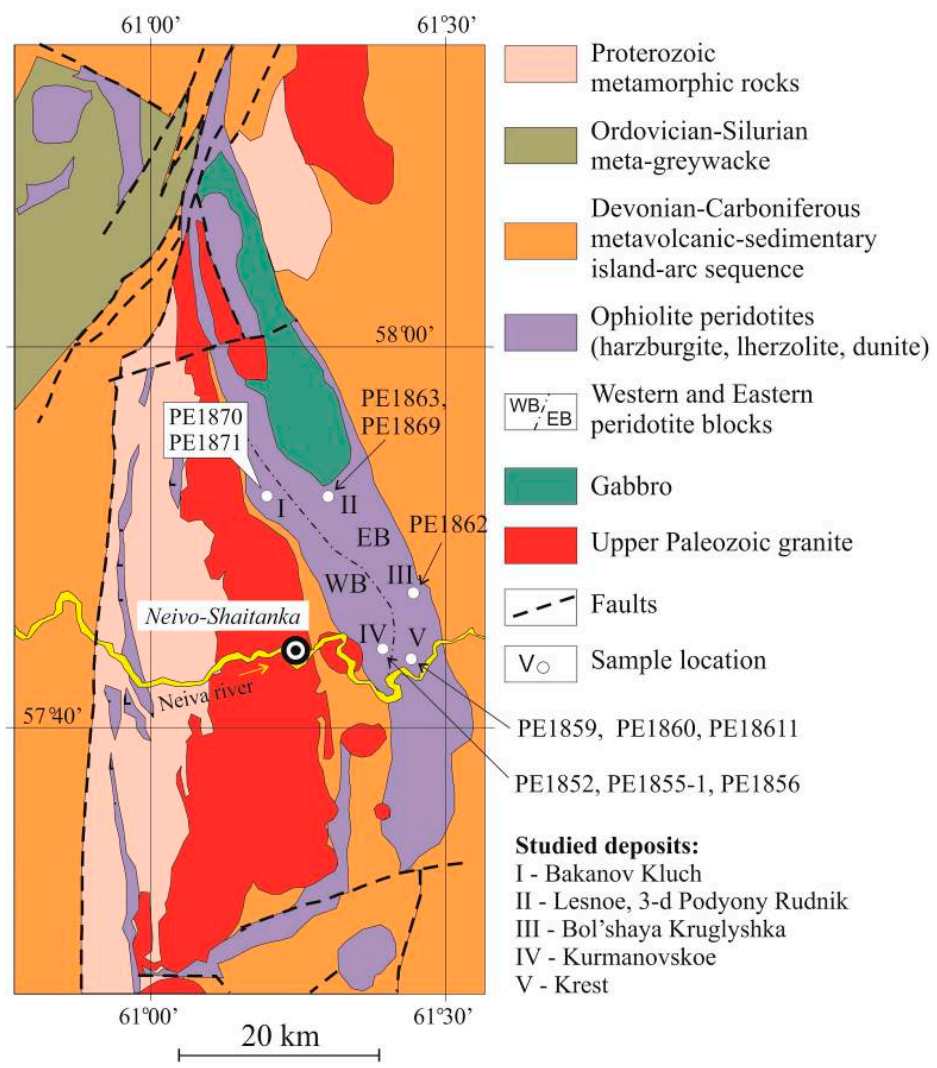

Figure 2. Simplified geological map of the Alapaevsk ophiolite massif showing the location of the chromite deposits, redrawn after [10].

\section{Previous Work and Description of the Chromite Deposits}

From the end of the 19th century until 1929 about 80 small Al-rich chromite deposits were discovered and mined in the Alapaevsk massif. This activity yielded more than 70 thousand tons of ore. In the second half of the 20th century several new chromite deposits, comprising Cr-rich ore, were discovered and exploited [8]. Some of these deposits contain more than 1 million tons of ore. More recently, the composition of chromite from the Alapaevsk chromite deposits was described and the presence of two types of chromite ore, Cr-rich and Al-rich, demonstrated [14-17]. A recent study [17] has demonstrated that the peridotite massif can be divided into Western and Eastern blocks (Figure 2). The Western block mostly consists of highly depleted dunite-harzburgite and contains Cr-rich chromite deposits. The Eastern block is composed of more homogeneous harzburgite that hosts Al-rich chromite deposits. In this contribution the following chromite deposits have been studied: Bakanov Kluch (samples PE1870 and PE1871) and Kurmanovskoe (samples PE1852, PE1855-1 and PE1856) from the Eastern block, and Lesnoe (sample PE1863), 3-d Podyony Rudnik (sample PE1869), Bol'shaya Kruglyshka (sample PE1862), and Krest (samples PE1859, PE1860, and PE1861) collected in the Western block (Figure 2). The samples were collected in the open pits (Figure 3) and they represent schlieren, banded, massive, and disseminated chromitite (Figure 4). Only the deposits of Bakanov Kluch and Lesnoe are currently mined and the deposit of Krest is under exploration. The other deposits are exhausted. The Bakanov Kluch chromite deposit comprises six ore bodies approaching $300 \mathrm{~m}$ in length and extending $300 \mathrm{~m}$ in depth, with a thickness varying from 1 to $4 \mathrm{~m}$. Chromitite shows a disseminated texture and the estimated resource is about 15 thousand tons. The mineralized area in the Kurmanovskoe chromite deposit is $>1 \mathrm{~km}$ long and 50-250 m wide. It consists of four large ore bodies and several smaller ones. The biggest ore body is about $800 \mathrm{~m}$ long and $250 \mathrm{~m}$ deep, with a thickness of 1-10 m. Disseminated chromitites are very common, accompanied by rare massive chromitites. Resources vary between 20 and 250 thousand tons. In the Lesnoe chromite deposit, four 
ore bodies have been identified. They are 25-73 m long, $70 \mathrm{~m}$ deep, and 0.3-4 $\mathrm{m}$ thick. Disseminated and massive chromitite occur in the deposit and the resource is estimated to be about 75 thousand tons. The 3-d Podyony Rudnik chromite deposit consists of nine blocks that contain several ore bodies of disseminated and massive chromitites. The ore zone is about $600 \mathrm{~m}$ long and $40 \mathrm{~m}$ wide. Some ore bodies approach $100 \mathrm{~m}$ in length and $120 \mathrm{~m}$ in depth, with a thickness of 3-12 $\mathrm{m}$. The Bol'shaya Kruglyshka chromite deposit consists of one ore body, about $130 \mathrm{~m}$ long, and $50 \mathrm{~m}$ deep, with a thickness of $0.3-2.5 \mathrm{~m}$. The body consists of massive and disseminated chromitite, that is, totally dismembered by faulting. Resources are about 7 thousand tons. The Krest deposit forms a small body of massive and disseminated chromite with a cruciform shape. It has a length of several meters and thickness of $0.5 \mathrm{~m}$, dipping sub-vertically. The source of this deposit is not known.
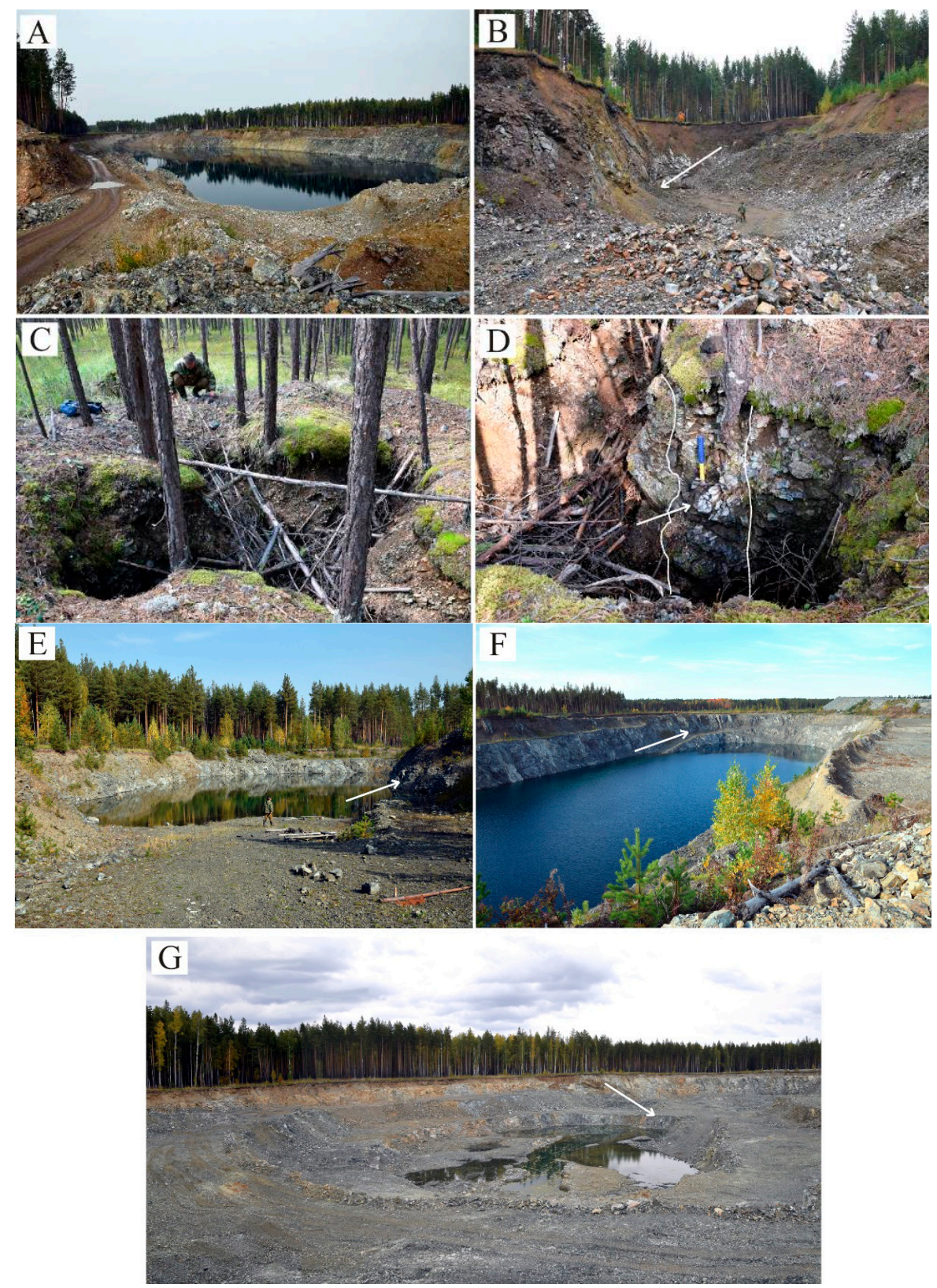

Figure 3. Overview of the chromite deposits of the Alapaevsk massif, Central Urals. Kurmanovskoe chromite deposit: (A) general view of open pit and (B) the location of the studied sample; Krest chromite deposit: (C) the exploration trench and (D) vertical ore body of massif chromite in dunite; (E) open pit of the Bol'shaya Kruglyshka chromite deposit; (F) open pit of the 3-d Podyony Rudnik chromite deposit; (G) open pit of the Lesnoe chromite deposit. Arrows indicate sample locations. 

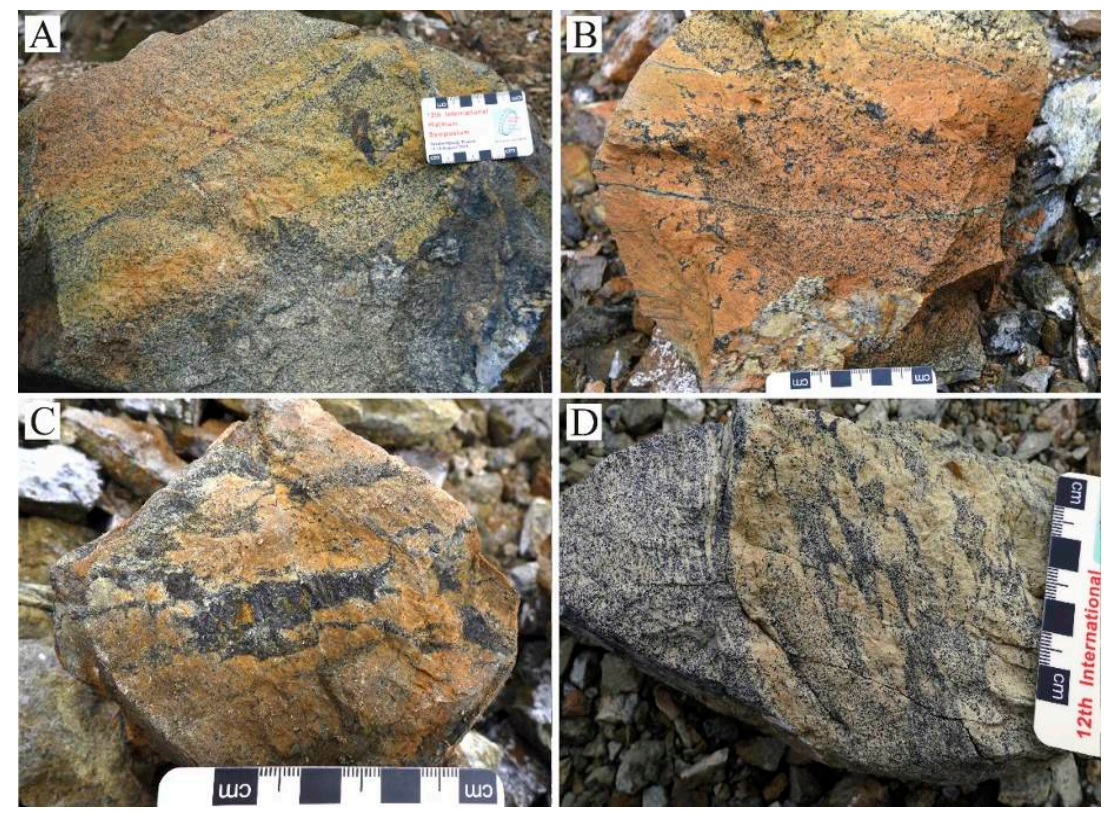

Figure 4. Different textural types of the chromite ores from the Alapaevsk massif, Central Urals. Chromite ore of the Kurmanovskoe deposit (number IV on map) (A-C). (A) Banded (sample PE1852) and massive (samples PE1855-1 and PE1856); (B) ores disseminated ore; (C) small schlieren of massive chromitite; (D) schlieren type of chromitite from the Bakanov Kluch chromite deposit (sample PE1870) (Ion map).

\section{Analytical Techniques}

Chromite, silicates, PGM, and other accessory minerals were analyzed by electron microprobe using a Superprobe Jeol JXA 8200 (JEOL, Tokyo, Japan) at the Eugen F. Stumpfl Laboratory at the University of Leoben, Austria, using both ED and WD systems. Back scattered electron (BSE) images were obtained using the same instrument. During the analyses of chromite and silicates, the electron microprobe was operated in the WDS mode, with an accelerating voltage of $15 \mathrm{kV}$ of and beam current of $10 \mathrm{nA}$. The analysis of $\mathrm{Na}, \mathrm{Mg}, \mathrm{K}, \mathrm{Al}, \mathrm{Si}, \mathrm{Ca}, \mathrm{Ti}, \mathrm{V}, \mathrm{Cr}, \mathrm{Zn}, \mathrm{Mn}, \mathrm{Fe}$, and $\mathrm{Ni}$ were obtained using the $\mathrm{K} \alpha$ lines, and were calibrated on natural chromite, rhodonite, ilmenite, albite, pentlandite, wollastonite, kaersutite, sphalerite, and metallic vanadium. The following diffracting crystals were used: TAP for $\mathrm{Na}, \mathrm{Mg}$, and $\mathrm{Al}$; PETJ for $\mathrm{K}, \mathrm{Si}$, and $\mathrm{Ca}$; and $\mathrm{LIFH}$ for $\mathrm{Ti}, \mathrm{V}, \mathrm{Cr}, \mathrm{Zn}, \mathrm{Mn}, \mathrm{Fe}$, and Ni. The peak and backgrounds counting times were 20 and $10 \mathrm{~s}$, respectively, for the major elements. They were increased to 40 and 20 for trace elements, such $\mathrm{Ca}, \mathrm{Ni}$, and $\mathrm{Mn}$ in olivine. The detection limits were automatically calculated by the microprobe software and they are listed in the following as ppm: $\mathrm{Na}$ (150), Mg (100), K (80), Al (150), Si (250), Ca (50), Ti (250), V (150), Cr (200), Zn (200), Mn (100), and $\mathrm{Ni}$ (150). The amount of $\mathrm{Fe}^{3+}$ in chromite was calculated assuming the ideal spinel stoichiometry. About 500 analyses of chromite were performed on 11 samples and a selection of them is listed in Table A1 (see Appendix A). Representative analyses of silicates are presented in Tables A2 and A3 (see Appendix A). PGM and other accessory minerals were located by scanning polished sections under a reflected light microscope at 250-800 magnification. The accessory minerals with a size less than $5 \mu \mathrm{m}$ were only qualitatively analyzed by EDS. The larger accessory minerals were quantitatively analyzed in the WDS mode, at $20 \mathrm{kV}$ accelerating voltage and $10 \mathrm{nA}$ beam current, and beam diameter of about 1 micron. The peak and background counting times were 15 and $5 \mathrm{~s}$, respectively. The $\mathrm{K} \alpha$ lines were used for $\mathrm{S}, \mathrm{As}, \mathrm{Fe}, \mathrm{Ni}$, and $\mathrm{P} ; \mathrm{L} \alpha$ for $\mathrm{Ir}, \mathrm{Ru}, \mathrm{Rh}, \mathrm{Pd}$, and $\mathrm{Pt}$, and $\mathrm{M} \alpha$ for Os. The reference materials were pure metals for the six PGE ( $\mathrm{Ru}, \mathrm{Rh}, \mathrm{Pd}, \mathrm{Os}$, Ir, and Pt), synthetic NiS, natural pyrite, and niccolite for $\mathrm{Ni}, \mathrm{Fe}, \mathrm{S}$, and $\mathrm{As}$; and apatite for P. The following diffracting crystals were selected: PETJ for S and P; PETH for Ru, Os, and Rh; LIFH for Fe, Ni, Ir, and Pt; and TAP for As. Automatic 
corrections were performed for interferences involving $\mathrm{Ru}-\mathrm{Rh}$ and $\mathrm{Rh}-\mathrm{Pd}$. Analyses of accessory minerals are listed in Tables A4 and A5 (see Appendix A). Platinum was never detected and it was removed from Table A4 (see Appendix A).

\section{The Alapaevsk Chromitites}

\subsection{Texture and Mineral Chemistry of the Chromite}

Under the microscope, most of the samples consist of massive chromitite, containing a modal proportion less than $10 \%$ of interstitial silicate (Figure $5 \mathrm{~A}-\mathrm{D})$.
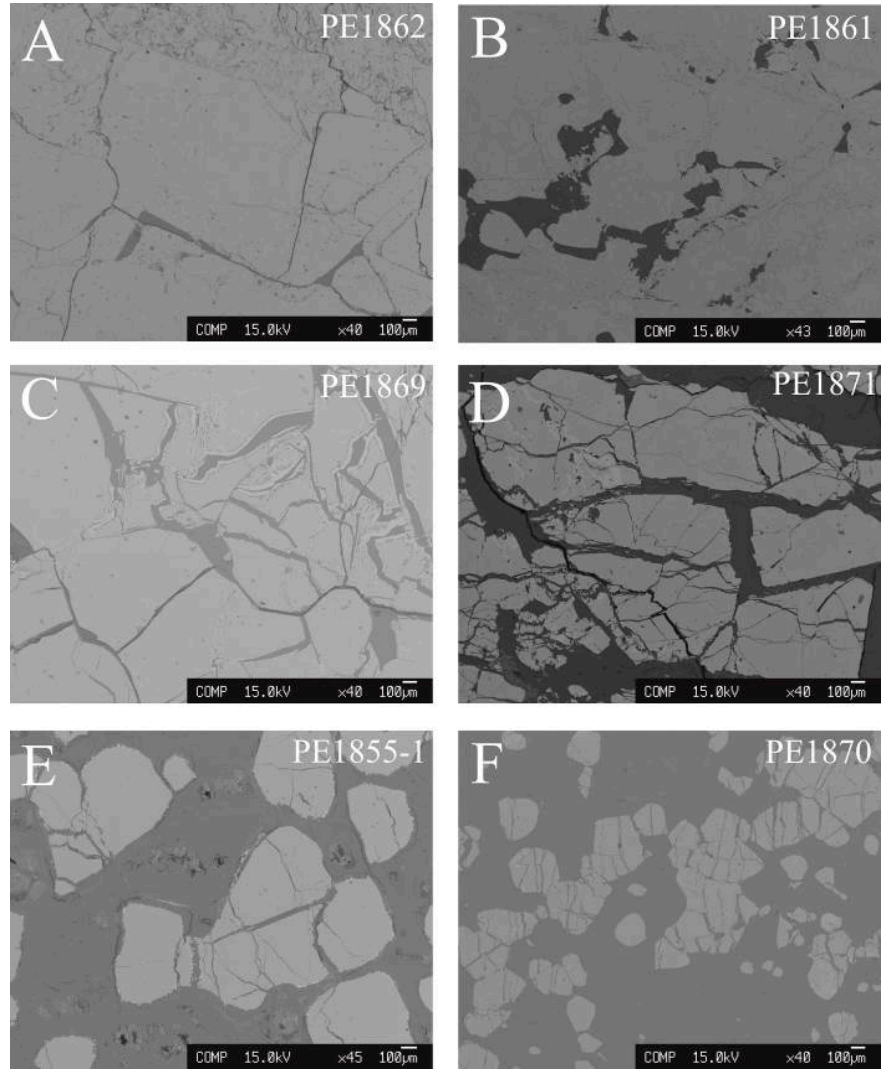

Figure 5. Back-scattered electron images of polished sections from the Alapaevsk chromitites (light grey $=$ chromite, dark grey $=$ altered silicates). (A) Massive and partially brecciated chromite from Bol'shaya Kruglyshka; (B) massive chromite from Krest; (C) massive chromite from 3-d Podyony Rudnik showing ferrian chromite alteration (lighter gray) developed along cracks and fissures; (D) massive chromite with ferrian chromite alteration (lighter gray) from Bakanov Kluch; (E) massive chromite with about $40 \%$ of altered silicates from Kurmanovskoe; (F) massive chromite with about $40 \%$ of altered silicates showing pull-apart texture from Bakanov Kluch.

In the samples PE1852 from Kurmanovskoe deposit, PE1859 from Krest, PE1855-1 Kurmanovskoe, and PE1870 from Bakanov Kluch the interstitial silicates are more abundant, reaching about 30\% by volume (Figure 5E,F). The massive chromitite shows, in some cases, a brecciated texture (Figure 5A,B ) and it is cut by cracks filled with interstitial silicates (Figure 5C,D) and pull-apart fractures (Figure 5E,F). Chromite is generally fresh, showing the typical ferrian-chromite alteration along grain boundaries and cracks (Figure 5C-E). Silicates in the matrix are mostly altered to chlorite, talc, and serpentine. Interstitial olivine has been found only in the sample PE1855-1 collected in the Kurmanovskoe deposit. Selected analyses obtained on unaltered cores of chromite grains are listed in Table A1 and plotted in the binary diagrams of Figure 6A-C. 


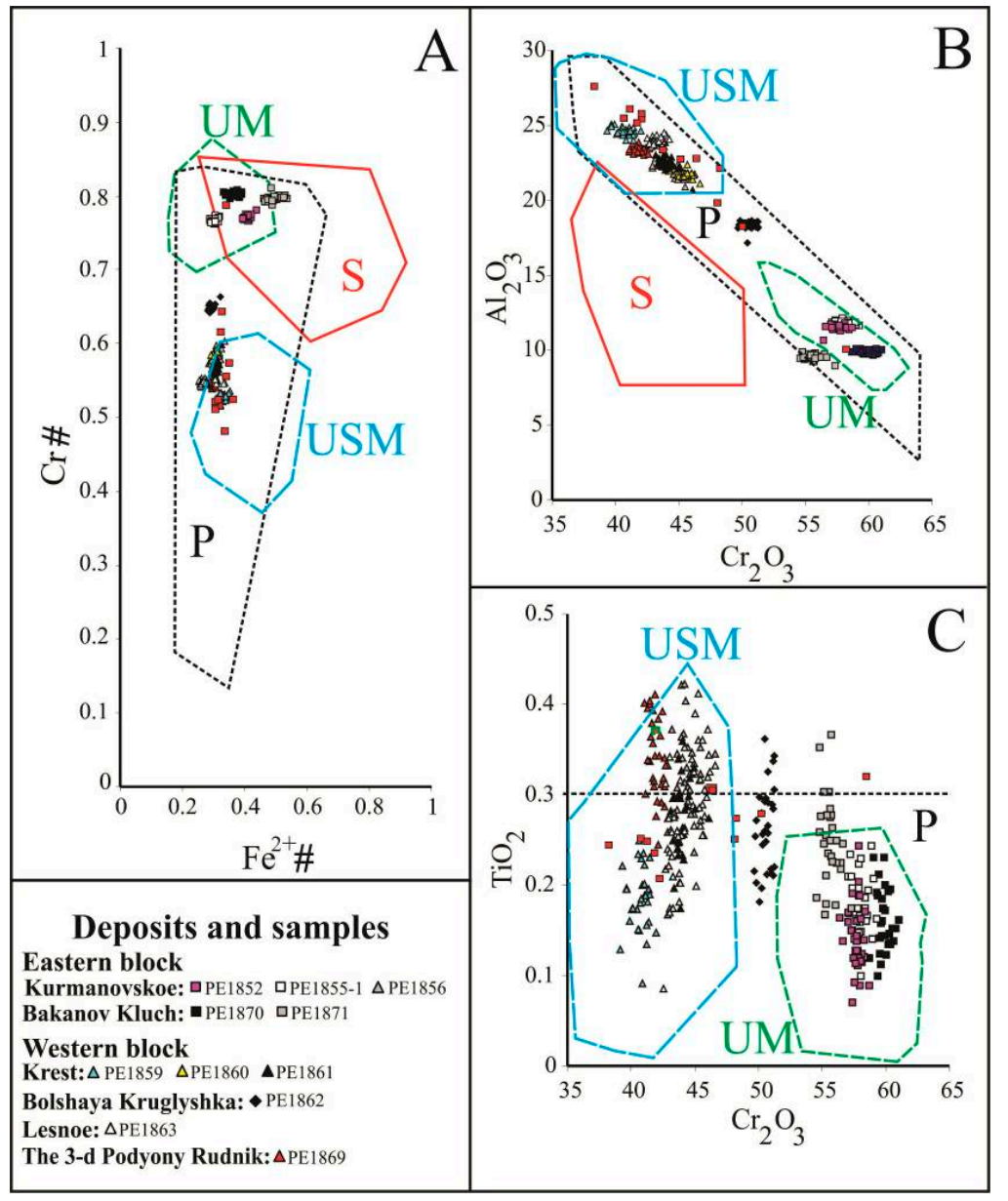

Figure 6. Composition of unaltered chromite from the Alapaevsk chromitite. (A) Variation of the chromium number, $\mathrm{Cr} \#=\mathrm{Cr} /(\mathrm{Cr}+\mathrm{Al})$, and bivalent iron number, $\mathrm{Fe}^{2+} \#=\mathrm{Fe}^{2+} /\left(\mathrm{Fe}^{2+}+\mathrm{Mg}\right)$; (B) negative correlation of $\mathrm{Al}_{2} \mathrm{O}_{3}$ versus $\mathrm{Cr}_{2} \mathrm{O}_{3}$; (C) variation of $\mathrm{Cr}_{2} \mathrm{O}_{3}$ and $\mathrm{TiO}_{2} . \mathrm{P}=$ field of podiform chromitites; $\mathrm{S}=$ field of stratiform chromitites; $\mathrm{UM}=$ field of the Uralian chromitites hosted in the ophiolitic mantle; USM = field of the Uralian chromitites hosted in the supra-Moho cumulates [6,18-20]. Red square $=$ literature data from [21].

The Alapaevsk chromitites plot in the podiform field on the $\mathrm{Cr} \#$ versus $\mathrm{Fe}^{2+} \#$ binary diagram (Figure 6A) and the compositions form an almost continuous trend from $\mathrm{Cr}$-rich (Cr\# up to 0.83), to intermediate and $\mathrm{Al}$-rich (minimum $\mathrm{Cr} \#=0.48$ ). The variation range in $\mathrm{Fe}^{2+} \#$ is $0.24-0.38$ in the chromitites from the Western block and 0.39-0.56 in those from the Eastern block (Figure 6A). A good negative correlation is observed between $\mathrm{Cr}_{2} \mathrm{O}_{3}$ and $\mathrm{Al}_{2} \mathrm{O}_{3}$ (Figure 6B), consistent with the $\mathrm{Al}-\mathrm{Cr}$ substitution predominant in podiform chromitites compared to the stratiform type [18-20]. According to the same diagram, the chromitites from Bakanov Kluch and Kurmanovskoe, located in the Western block, are $\mathrm{Cr}$-rich, having a $\mathrm{Cr}_{2} \mathrm{O}_{3}$ content higher than $50 \mathrm{wt} \%$ and $\mathrm{Al}_{2} \mathrm{O}_{3}$ below 15 wt \%. Al-rich chromitites with $\mathrm{Cr}_{2} \mathrm{O}_{3}$ content lower than $50 \mathrm{wt} \%$ and $\mathrm{Al}_{2} \mathrm{O}_{3}$ higher than $15 \mathrm{wt} \%$ have been found in the 3-d Podyony Rudnik, Krest, Lesnoe deposits (Eastern block) and Kurmanovskoe deposit (Western block). The chromitite from Bol'shaya Kruglyshka of the Western block displays an intermediate composition with $\mathrm{Cr}_{2} \mathrm{O}_{3}$ content about $50 \mathrm{wt} \%$ and $\mathrm{Al}_{2} \mathrm{O}_{3}$ higher than $15 \mathrm{wt} \%$. These data are in agreement with those previously reported by [21] from Alapaevsk chromitites.

The Kurmanovskoe deposit (Eastern block) is the only one in which both Cr-rich and Al-rich chromitites have been found (Figure 6B). The diagrams of Figure 6 show that most of the Cr-rich chromites analyzed in the Alapaevsk chromitites plot in the field of those hosted in the mantle sequence of selected Uralian ophiolites [ 6 and reference therein]. The composition of the Al-rich chromites 
displays similarity with the chromitites found in the cumulate sequence [6 and references therein]. $\mathrm{TiO}_{2}$ is generally lower than $0.3 \mathrm{wt} \%$ in most of the samples, as is typical for podiform chromitites (Figure 6C). However, several samples contain up to $0.42 \mathrm{wt} \%$ of $\mathrm{TiO}_{2}$ (Figure 6C).

\subsection{Accessory Minerals and Silicate Inclusions}

Several PGM have been found in the samples collected in the Kurmanovskoe and Krest deposits. On the basis of their chemical composition, laurite, cuproiridsite, and alloys of Os-Ru-Ir and Ir-Os-Ru have been identified. They occur as small grains (less than $10 \mu \mathrm{m}$ in size) in the following textural positions: (1) included in fresh chromite crystals (Figure 7A-C); (2) in the contact between chromite and the silicate matrix (Figure 7D); or (3) associated with altered minerals, such as ferrian-chromite (Figure 8A), awaruite, Fe-oxides, and chlorite (Figure 8C,D).
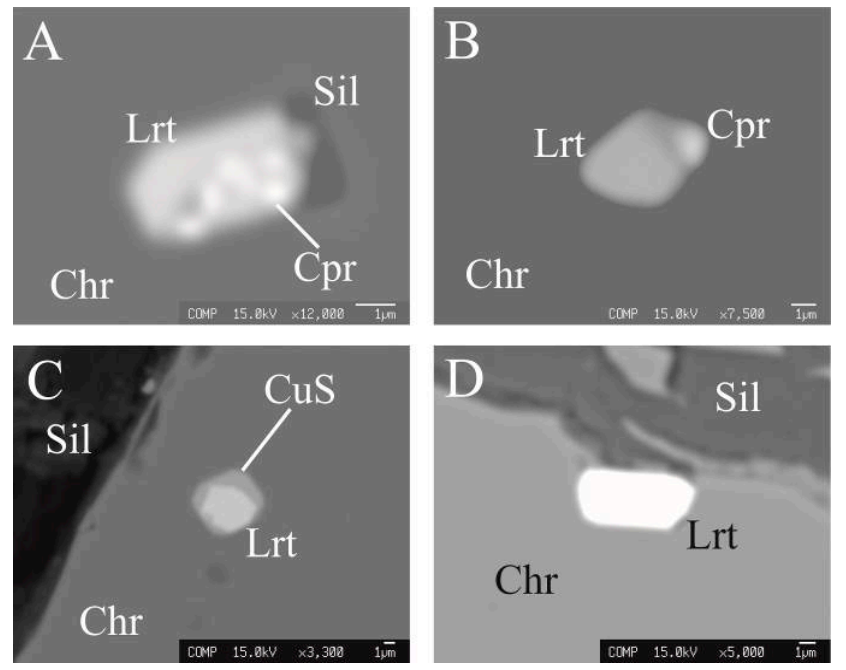

Figure 7. Back-scattered electron (BSE) images of magmatic PGM associated with the chromitites of Kurmanovskoe, from Alapaevsk ophiolite. (A,B) Crystals composed of laurite and cuproiridsite included in fresh chromite; (C) laurite associated with a $\mathrm{Cu}$-sulfide, included in fresh chromite; (D) single phase laurite in crack. Abbreviations: $\mathrm{Chr}=$ chromite; Lrt = laurite; $\mathrm{Cpr}=$ cuproiridsite, Sil $=$ silicates; $\mathrm{CuS}=\mathrm{Cu}$-sulfide.

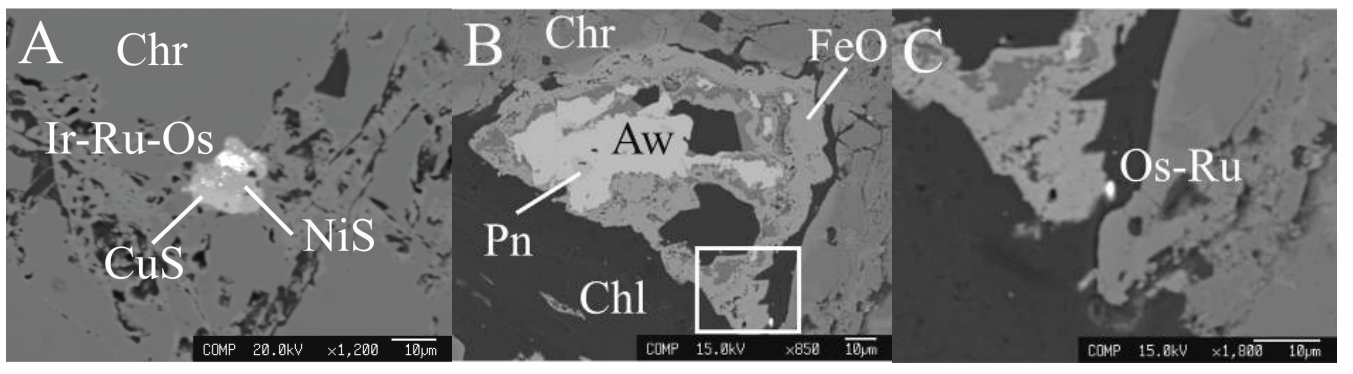

Figure 8. Back-scattered electron (BSE) images of secondary PGM associated with the chromitites from Alapaevsky. (A) Irregular alloy of Ir, Ru, Os, Ni-sulfide and Cu-sulfide in contact with ferrian chromite, from the chromitite of Kurmanovskoe; (B) complex grain composed pentlandite, awaruite, Fe-oxide or hydroxide in contact with ferrian-chromite and chlorite (Krest); (C) enlargement of (B) showing an alloy composed of Os and Ru. Abbreviations: Ir-Ru-Os = iridium alloy; Aw = awaruite; Pn = pentlandite; $\mathrm{Fe}-\mathrm{O}=$ Fe-oxide or hydroxide; $\mathrm{Chl}$ = chlorite; $\mathrm{Os}-\mathrm{Ru}=$ osmium alloy; other abbreviations = see Figure 7.

Laurite is the most abundant PGM and it forms polygonal grains, most of them included in fresh chromite (Figure 7A-C). Only one laurite grain was found in the contact between chromite and a 
crack filled with chlorite (Figure 7D). Laurite occurs as single phase (Figure 7D) or associate with cuproiridsite (Figure 7A,B) and with a Cu-sulfide (Figure 7C). The composition of laurite has been plotted in the Ru-Os-Ir triangle (Figure 9) and compared with those reported from relevant Uralian podiform chromitites. The laurite from Alapaevsky displays a limited compositional range of $\mathrm{Ru}-\mathrm{Os}$ substitution with a minimal amount of Ir (Figure 9) compared with laurite in the chromitites from the Kluchevskoy [9], Kempirsai [22], Ray-Iz [23] and Voikar-Sininsky [24] ophiolites. Cuproiridsite was too small to be quantitatively analyzed. It is exclusively associated with laurite as an inclusion in fresh chromite crystals (Figure 7A,B). Laurite and cuproiridsite have been found in the Cr-rich chromitites of Kurmanovskoe. One irregular grain composed of Ni-sulfide, $\mathrm{Cu}$-sulfide and an $\mathrm{Ir}-\mathrm{Ru}-\mathrm{O}$ s alloys was found in the ferrian-chromite of the Kurmanovskoe chromitite (Figure 8A). Due to its small size, it was qualitatively analyzed by EDS. An Os-Ru alloy was qualitatively analyzed in the chromitite of Krest. It occurs as a small bleb, about $2 \mu \mathrm{m}$ in size, in a complex grains composed of pentlandite, awaruite, Fe-oxides, and chlorite (Figure 8D).

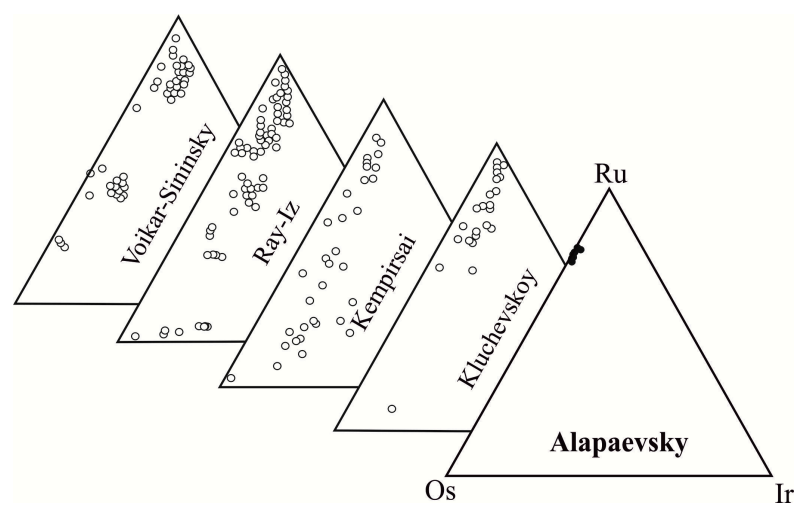

Figure 9. Plots (at.\%) of the compositions of laurite from chromitites of Alapaevsk (present study) compared with those analyzed in selected ophiolitic chromitites of the Urals (data from [9,20-22]).

A small grain (about $20 \mu \mathrm{m}$ ) yellow in color under a reflected-light microscope, was found in the interstitial serpentine of the Bakanov Kluch chromitite (Figure 10). According to the quantitative electron microprobe analyses (Table A5), it contains $\mathrm{Ni}$ as the most abundant element (88.05-89.89 wt \%), P (9.41-10.19 wt \%) and minor amounts of Fe (1.13-1.3 wt \%). The ideal calculated stoichiometry, based on the average of 10 analyses, is (Ni,Fe) $)_{5} \mathrm{P}$ (Figure 11, Table A5) (see Appendix A). Its composition has been plotted in the binary diagram presented in Figure 11 and compared with the only five Ni-phosphides accepted by the International Mineralogical Association (IMA) as mineral species, namely nickel phosphide [25,26]), melliniite [27]), halamishite, negevite, and transjordanite [28]. The diagram shows that the analyzed $(\mathrm{Ni}, \mathrm{Fe})_{5} \mathrm{P}$ in the Alapaevsk chromitite contains the highest value of $\mathrm{Ni}$ and it shows the highest $\mathrm{Ni} / \mathrm{P}$ ratio.

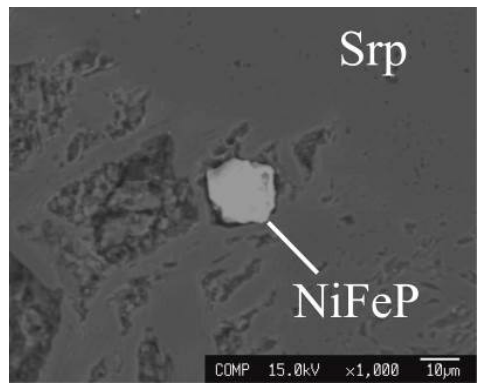

Figure 10. Back-scattered electron (BSE) image of a Ni-Fe phosphide found in the interstitial serpentine of the Bakanov Kluch chromitite. 


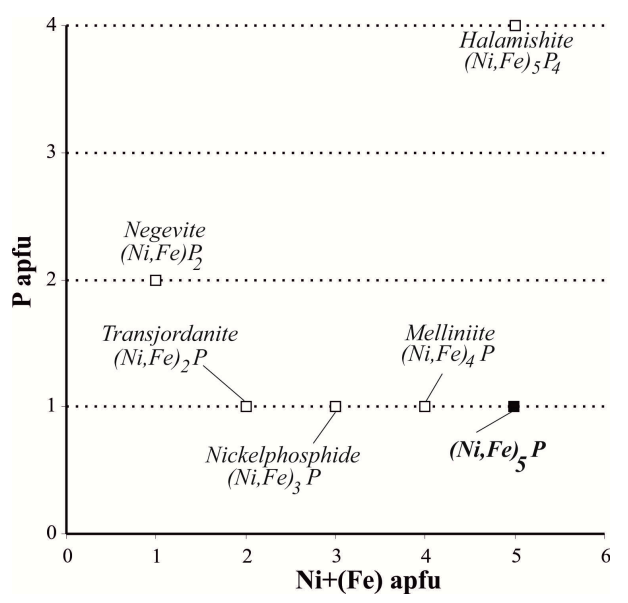

Figure 11. Binary diagram of $\mathrm{P}$ versus $\mathrm{Ni}+(\mathrm{Fe})$, apfu (atoms per formula unit), showing the composition of the Ni-phosphide found in the Bakanov Kluch chromitite (black square), compared with those of the minerals with $\mathrm{Ni}>\mathrm{Fe}$ described in the system $\mathrm{Ni}-\mathrm{Fe}-\mathrm{P}$ (open squares). Literature data from [25-28].

Although most of the silicate in the Alapaevsk chromitite has been totally altered to serpentine, talc, and chlorite, a few grains of fresh olivine have been found in the $\mathrm{Cr}$-rich chromitites from Kurmanovskoe (Western block). Olivine occurs as irregular grains located among the chromite crystals, or forming polygonal crystals (up to about $100 \mu \mathrm{m}$ ) included in the fresh chromite (Figure 12A,B).
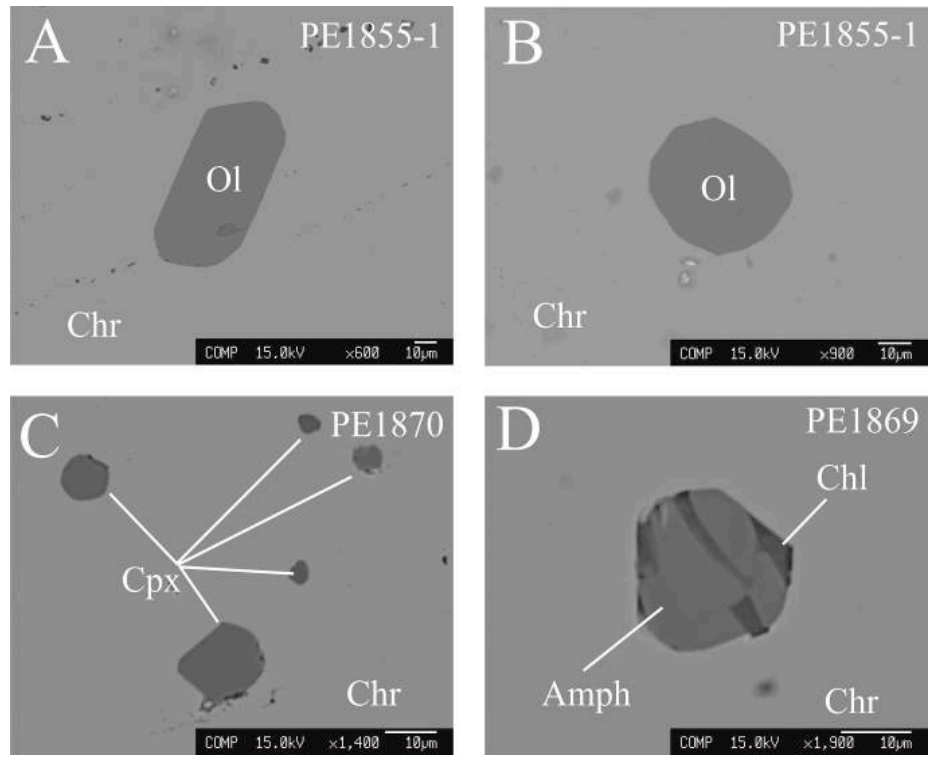

Figure 12. Back-scattered electron (BSE) images of silicates included in the Alapaevsk chromitites. Polygonal olivine in the chromitite from Kurmanovskoe (A,B); grains of clinopyroxene in the chromitite from Bakanov Kluch (C); inclusion composed of amphibole and chlorite found in the chromitite form 3-d Podyony Rudnik (D). Abbreviations: Ol = olivine; Cpx = clinopyroxene; Amph = amphibole; other abbreviations $=$ see Figures 7 and 8 .

Amphibole, clinopyroxene, Na-rich phlogopite, and chlorite have been also found as small inclusions in fresh chromite crystals (Figure 12C,D). Olivine is characterized by a narrow compositional range with $95.75 \%$ to $96.16 \%$ forsterite in the interstitial olivine, and $96.83 \%$ to $97.06 \%$ forsterite in the olivine included in chromite (Table A2). The Ni, Mn and Ca contents are similar in interstitial 
olivine and olivine included in chromite (Figure 13). The $\mathrm{NiO}$ wt \% content varies between 0.3 and 0.45 (Table A2). The highest value of $\mathrm{MnO}(0.15 \mathrm{wt} \%)$ was encountered in one interstitial olivine (Figure 13B), whereas all the other olivine contains 0.01 to $0.09 \mathrm{wt} \% \mathrm{MnO}$ (Table A2). In most of the olivine, $\mathrm{Ca}$ is below $900 \mathrm{ppm}$ and its minimum value of $400 \mathrm{ppm}$ was found in the interstitial olivine (Table A2). The $\mathrm{Cr}_{2} \mathrm{O}_{3}$ content is higher in the included olivine (0.47-0.75 wt \%) than in the interstitial olivine (0.06-0.19 wt \%) (Table A2).
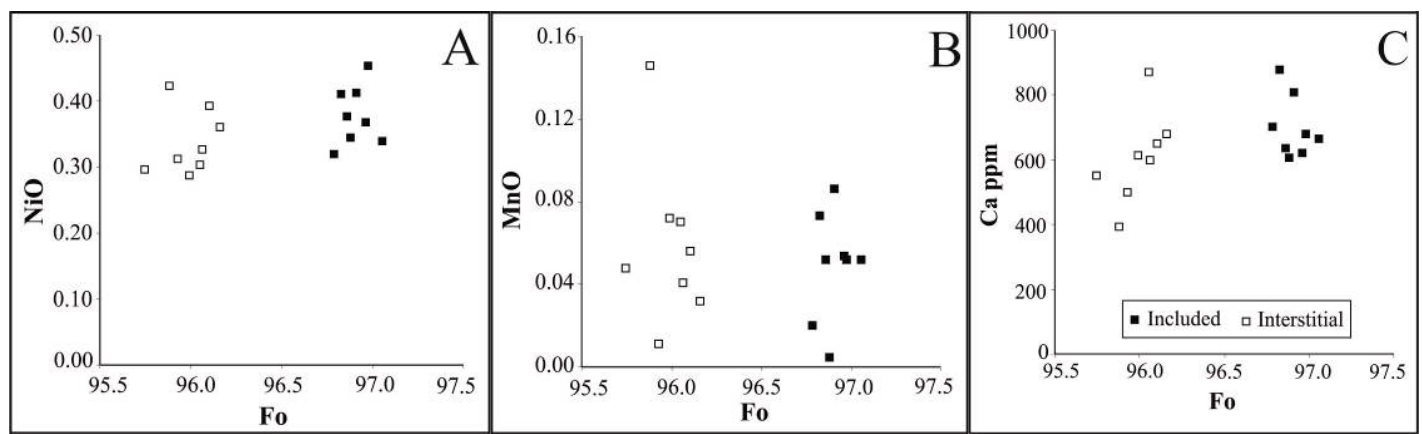

Figure 13. Variation of $\mathrm{NiO}(\mathbf{A}), \mathrm{MnO}(\mathbf{B})$ and $\mathrm{CaO}(\mathbf{C})$ as a function of forsterite $\mathrm{mol} \%$ in the olivine in the Cr-rich chromitites from Kurmanovskoe.

Amphibole included in fresh chromite has been analyzed in the Al-rich chromitites from Krest and 3-d Podyony Rudnik and in Cr-rich chromitite from Bakanov Kluch (Figure 14A). With the exception of one amphibole grain found in the Bakanov Kluch deposit that plots in the field of tschermakite, all the analyzed amphiboles can be classified as magnesiohornblende (Figure 14A). The analyzed amphiboles contain $\mathrm{Al}_{2} \mathrm{O}_{3}$ from $9.19 \mathrm{wt} \%$ to $10.01 \mathrm{wt} \%$ and $\mathrm{CaO}$ from $11.46 \mathrm{wt} \%$ to $12.34 \mathrm{wt} \%$. They show appreciable amounts of $\mathrm{Cr}_{2} \mathrm{O}_{3}$ (up to $3.29 \mathrm{wt} \%$ ) and $\mathrm{Na}_{2} \mathrm{O}$ (up to $3.73 \mathrm{wt} \%$ ). The content of $\mathrm{TiO}_{2}$ is variable, ranging from $0.41 \mathrm{wt} \%$ to $2.04 \mathrm{wt} \%$. The amounts of $\mathrm{MnO}, \mathrm{NiO}$, and $\mathrm{K}_{2} \mathrm{O}$ are always below 1 wt \% (Table A3).

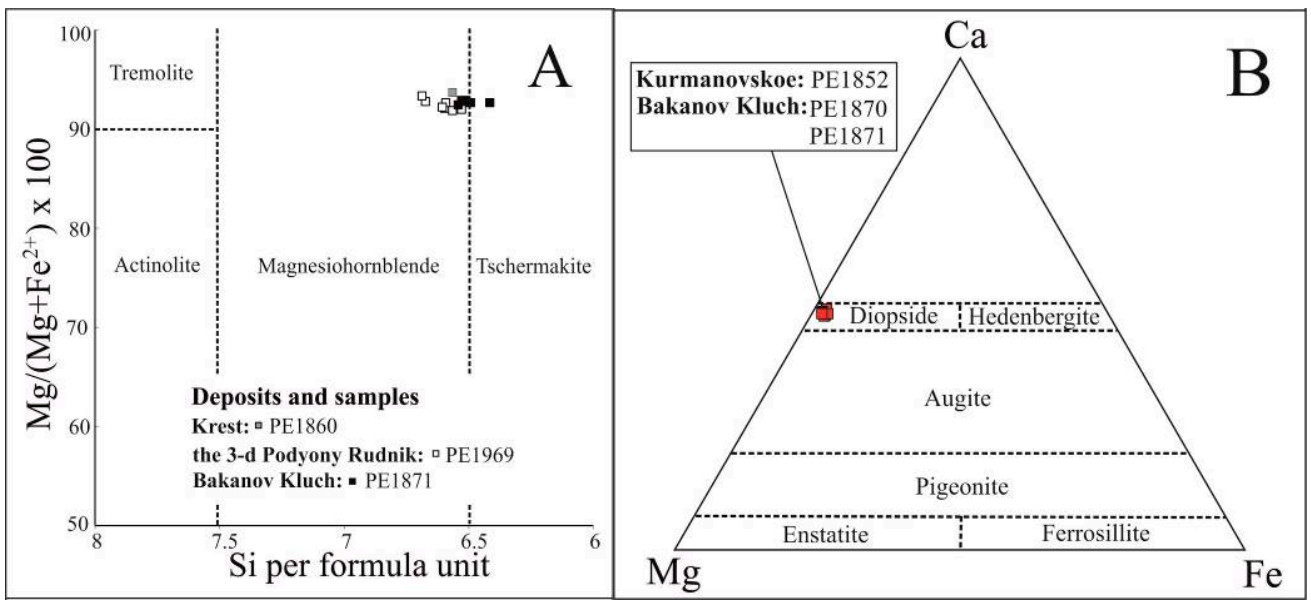

Figure 14. Compositional variations of silicates included in chromite from the Alapaevskychromitites. Binary diagram for the classification of the amphibole (A); ternary diagram for the classification of the pyroxenes (B). Simplified after [29].

Inclusions of clinopyroxene occur in the chromite of the chromitites from Kurmanovskoe and Bakanov Kluch (Figure 14B). These have a similar composition within the diopside field (Figure 14B). They contain $\mathrm{Cr}_{2} \mathrm{O}_{3}$ (up to $1.91 \mathrm{wt} \%$ ) and very low amounts of $\mathrm{MnO}, \mathrm{NiO}, \mathrm{TiO}_{2}, \mathrm{Na}_{2} \mathrm{O}$, and $\mathrm{K}_{2} \mathrm{O}$ (Table A3). Small inclusions of phlogopite have been identified by qualitative analysis. 


\section{Discussion and Conclusions}

\subsection{Chromite Composition and Silicate Inclusion: Their Application to Define the Tectonic Setting of the Host} Chromitite and Its Genesis

Chromite is widely accepted to be an important petrogenetic indicator and it can be used to define the geodynamic setting in which chromitites and their host rocks formed [29-39]. According to the morphology of the ore body and the chromite composition, chromitites belong to two main groups: (1) stratiform chromitites that form layers of massive chromite associated with mafic-ultramafic cumulates in the lower part of continental layered intrusions and supra-Moho cumulate sequences of ophiolites and (2) podiform chromitites that consist of lenses, pods, and schlieren, mainly occurring in the mantle section of ophiolites, orogenic lherzolites, and in the dunitic portion of Ural-Alaskan complexes [6,29-36]. In the ophiolites of the Urals, both the mantle-hosted podiform chromitites as well as the supra-Moho stratiform chromitites have been described ([6] and references therein). According to [6] (and references therein), chromitites hosted in the Uralian ophiolites are characterized by distinctive chromite compositions. In particular, most of the podiform chromitites hosted by ophiolitic mantle rocks and a few examples of supra-Moho layered chromitites are $\mathrm{Cr}$-rich and Ti-poor $\left(\mathrm{TiO}_{2}\right.$ less than $\left.0.3 \mathrm{wt} \%\right)$ [6]. In contrast, the majority of the supra-Moho chromitites are Al-rich and characterized by a variable content of $\mathrm{TiO}_{2}(0.15 \mathrm{wt} \%$ to $0.8 \mathrm{wt} \%)$. Confirming the previous work by $[8,14-17,21]$, the composition of the Alapevsky chromite indicates the coexistence of the Al-rich and Cr-rich chromitites, a common feature of many ophiolitic belts worldwide [22,36-50].

The bi-modal distribution of Al-rich and Cr-rich chromitite in the Urals ophiolites has been interpreted using two models. The first implies a change in the geodynamic setting, with the Al-rich chromitite generated in the mid-ocean ridge, whereas the Cr-rich chromitite forms in a supra-subduction zone (SSZ) setting. The second model suggested that the bimodal distribution was due to a vertical zoning in the ophiolite sequence, with the Cr-rich chromitite located in the deep mantle section and the Al-rich chromitite occurring higher in the succession, close to or above the Moho transition [6,22].

To better understand the origin of Al-rich chromitites and $\mathrm{Cr}$-rich chromitites in the Alapaevsk ophiolite, the $\mathrm{TiO}_{2}$ content of chromite has been plotted versus $\mathrm{Al}_{2} \mathrm{O}_{3}$ (Figure 15). In Figure 15A, one group of analyses falls in the $\mathrm{Al}_{2} \mathrm{O}_{3}$ poor field of spinels from the SSZ peridotite and a second group of samples clusters in the overlapping field between SSZ and MORB chromites. A few samples are slightly enriched in $\mathrm{TiO}_{2}$. The diagram of Figure 15B shows that the low-Ti, $\mathrm{Cr}$-rich chromitites from Bakanov Kluch and Kurmanovskoe fall in the field of Island Arc Basalts (IAB). The Al-rich chromitites display compositional similarity with those reported from chromitites in supra-Moho cumulate sequences of the Urals (data from [6]). According to the $\mathrm{TiO}_{2}-\mathrm{Al}_{2} \mathrm{O}_{3}$ relationships, we can deduce that the Alapaevsk chromitites formed in an SSZ, in agreement with [15,17], implying formation of Cr-rich chromitites in the deep mantle, and the Al-rich close to the Moho transition. The high-Cr chromitites are assumed to have formed by reaction of boninitic melts with residual harzburgite. The nature of the melt parental to Al-rich chromitites is uncertain. They may have formed from a single batch of boninitic melt evolving during its ascent to the shallow upper mantle. Alternatively, the Al-rich chromitites might have resulted from mixing between boninite and MORB-type melts. The composition of olivine can be used, with caution, to distinguish olivine formed deep in the mantle from olivine crystallized in the crust by mafic and ultramafic magmas [51,52]. Olivine is a common accessory mineral in most chromitites, including those of Alapaevsk, although it rarely survives the serpentinization. As a consequence, few grains of fresh olivine generally occur in the silicate matrix of the chromitites. Some occur as inclusions in unaltered chromites, reflecting their magmatic origin. In the Alapaevsk chromitite both types of olivine, i.e., interstitial and included, have been recognized in the Kurmanovskoe deposits. The composition of olivine in chromitite is strongly influenced by the element partitioning with chromitite. Several analyses reported from the Urals have shown that olivine displays a wide range of forsterite molar \% with $\mathrm{Ni}, \mathrm{Mn}$, and Ca contents according to the type of host 
chromitite [6]. In particular, most of the olivine associated with ophiolitic mantle chromitites displays high (94-98 mol \%) forsterite and $\mathrm{NiO}$ between 0.35 and $1.15 \mathrm{wt} \%$. MnO wt \% and $\mathrm{Ca}(\mathrm{ppm})$ are very low. All of the analyzed olivine grains, interstitial and included, from Kurmanovskoe chromite deposit are characterized by values of forsterite, $\mathrm{NiO}, \mathrm{MnO}$, and $\mathrm{Ca}$ (Figure 13) very similar to those reported from the ophiolitic mantle-hosted chromitites from the Urals [6]. This observation suggests that the olivine from Kurmanovskoe and its host chromitites were generated in the mantle section of the Alapaevsk ophiolite as previously reported by $[15,17]$.

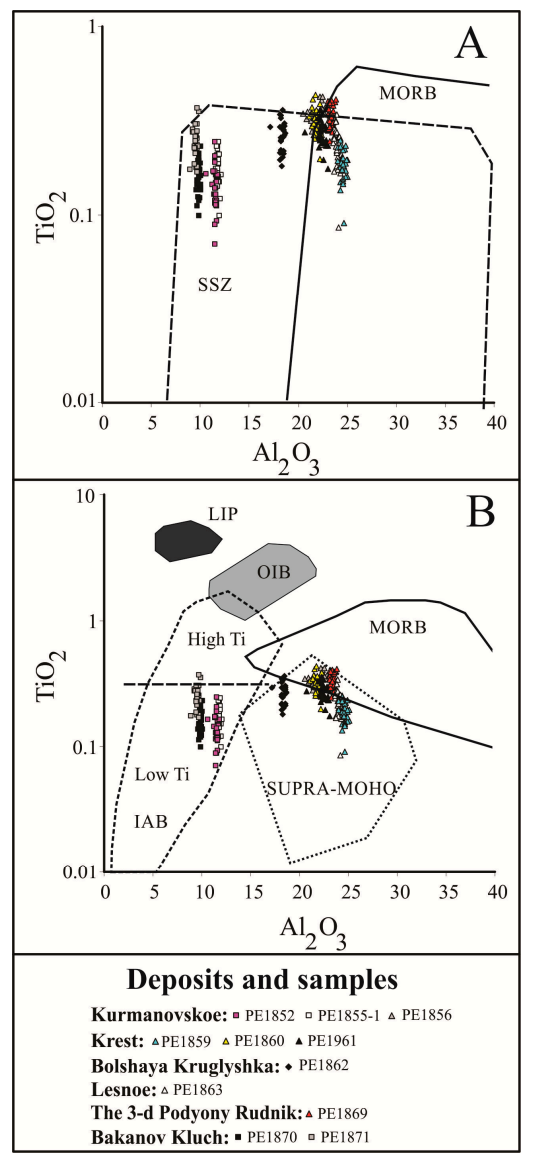

Figure 15. $\mathrm{TiO}_{2}-\mathrm{Al}_{2} \mathrm{O}_{3}$ relationships in chromitites of Alapaevsk. (A) Composition of the chromitites, compared to the field of spinels from the supra-subduction zone (SSZ) and mid-ocean ridge (MOR) mantle peridotites (compositional fields from [34]); (B) the fields for IAB (island arc basalt), OIB (oceanic island basalt), MORB (mid-ocean ridge basalt), LIP (large igneous province) basalt, and supra-Moho (SUPRA-MOHO) chromitite from the Urals are from [6,36]. The horizontal dashed line at $\mathrm{TiO}_{2}=0.30 \mathrm{wt} \%$ separates the high-Ti IAB (high-K calc-alkaline suite) from the low-Ti IAB (boninitic, tholeiitic).

One of the most accepted mechanisms of chromite crystallization to form large volumes of chromitites in ophiolitic mantle rocks invokes chromitite formation by melt-rock interaction. According to this model, chromitites represent the filling of magmatic conduits [53] and formed by reaction between ascending mantle melts and country-rock residual peridotite [54-58]. The same mechanism can be applied to the formation of the Alapaevsk chromitites. Several authors, using both mineralogical observations and experimental work, have demonstrated that melts that generate chromitites are generally enriched in water and fluids [54-62]. The suite of solid inclusions reported from the Alapaevesk chromitites, such as amphibole and phlogopite enriched in $\mathrm{NaO}$, indicates the presence of a melt with a relatively high water activity and carrier of some incompatible elements. Therefore, 
we can conclude that the Alapaevesk chromitites formed because of the interaction between melts enriched in fluids, water, and incompatible elements and mantle peridotite, a common feature during the formation of ophiolitic chromitites [54-62].

\subsection{Origin and Evolution of the PGM from High to Low Temperature}

The PGM found in the Alapaevsk chromitites consist of IPGE-rich phases, the common mineral assemblage of the chromitites hosted in the mantle sequence of ophiolite complexes. On the basis of their mode of occurrence, (included in fresh chromite crystal or associated with altered minerals), the PGM described in the Alapaevsk chromitites can be classified as: (1) primary PGM that formed in the high-temperature magmatic stages during the precipitation of the host chromite and (2) secondary PGM that originated during low-temperature processes. The primary PGM in the Alapaevsk chromitites consists of laurite and cuproiridsite (Figure 7A-C), while alloys in the Ir-Os-Ru system (Figure 8A-C) are considered to be secondary. The magmatic PGM have been found only in the Cr-rich chromitites from Kurmanovskoe deposits. The secondary PGM occur in both the $\mathrm{Cr}$-rich and Al-rich chromitites of Kurmanovskoe and Krest deposits. The origin of the primary PGM inclusions in the Alapaevsk chromitites can be explained by a crystallization process controlled by relative stability of IPGE alloys and sulfides as function of sulfur fugacity and temperature (Figure 16). The sulfur fugacity is expected to increase with decreasing temperature in magmatic systems. As a consequence, at high temperatures and low sulfur fugacity alloys of IPGE are the first PGM to precipitate, followed by laurite and finally by erlichmanite and Ir-bearing sulfides (Figure 16). The primary laurite of Alapaevsk shows a narrow variation of Os and $\mathrm{Ru}$ (Figure 9), well below the Os-OsS 2 buffer, as typical of laurite precipitated at high temperature and relatively low sulfur fugacity. Nevertheless, the absence of magmatic Os-Ir- $(\mathrm{Ru})$ alloys, the presence of cuproiridsite (Figure 7A,B), and the laurite-Cu sulfide association (Figure 7C) suggest that the sulfur fugacity was relatively high during the precipitation of the PGM in the magmatic stage of the chromitites from Alapaevsk, although lower than those reported in the Uralian chromitites from Kluchevskoy [9], Kempirsai [22], Ray-Iz [23] and Voikar-Sininsky [24], in which abundant erlichmanite has been analyzed, thus confirming a precipitation of the PGM under higher sulfur fugacity (Figures 9 and 16). The secondary PGM assemblage consists of very tiny grains (less than $4 \mu \mathrm{m}$ ) of Ir-Ru-Os and Os-Ru alloys (Figure 8). The Ir-Ru-Os alloy occurs in an irregular grain that consists of a Ni-sulfide and a Cu-sulfide (Figure 8A). The Os-Ru alloy occurs in a complex of grains composed of pentlandite, awaruite, Fe-oxides, and chlorite (Figure 8C,D). Very likely, the secondary IPGE alloys formed at low temperature, during the serpentinization process that affected the Alapaevsk ophiolite.

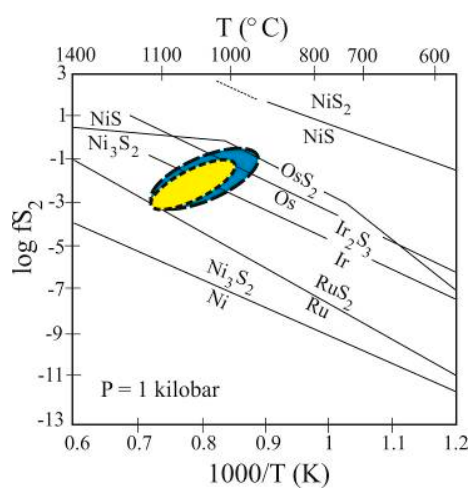

Figure 16. Metal-sulfide equilibrium curves for $\mathrm{Ru}$, Os, $\mathrm{Ir}$, and $\mathrm{Ni}$ as function of sulfur fugacity, expressed as $\log \mathrm{fS}_{2}$ and temperature. Yellow and blue fields show the conditions prevailing in mantle-hosted chromitites from ophiolites of the Urals. Yellow field = present work, blue field $=[9,22-24]$. 


\subsection{Natural Minerals in the Ni-Fe-P System}

Natural phases in the Ni-Fe-P system are rare, consisting of only five minerals with $\mathrm{Fe}>\mathrm{Ni}$, namely allabogdanite $(\mathrm{Fe}, \mathrm{Ni})_{2} \mathrm{P}$, barringerite $(\mathrm{Fe}, \mathrm{Ni})_{2} \mathrm{P}$, murashkoite $\mathrm{FeP}$, schreibersite $(\mathrm{Fe}, \mathrm{Ni})_{3} \mathrm{P}$, and zuktamrurite $\mathrm{FeP}_{2}$, [28,63-65]; and five minerals with $\mathrm{Ni}>\mathrm{Fe}$, such as halamishite $\mathrm{Ni}_{5} \mathrm{P}_{4}$, melliniite $(\mathrm{Ni}, \mathrm{Fe})_{4} \mathrm{P}$, negevite $\mathrm{NiP}_{2}$, nickelphosphide $(\mathrm{Ni}, \mathrm{Fe})_{3} \mathrm{P}$, and transjordanite $\mathrm{Ni}_{2} \mathrm{P}$ [25-28]. All these minerals have been found in meteorites, with the exception of schreibersite, which was also reported in reduced differentiated lenses in basalts and in hydrothermal replacement in petrified wood (http:/ / mindat. org). Pratesi et al. [27], based on the investigation of the crystal structure of selected minerals in the Ni-Fe-P system, argued that some of these compounds, characterized by high symmetry and atomic coordination, may crystallize in a high-pressure environment, such as the core of the Earth. The $(\mathrm{Ni}, \mathrm{Fe})_{5} \mathrm{P}$ from the Alapaevsk chromitite represents the first terrestrial occurrence of a Ni phosphide. Its chemical composition reveals that it contains the most $\mathrm{Ni}$ among the minerals known in the Ni-Fe-P system (Figure 11) and it represents a new mineral species.

Acknowledgments: The University Centrum for Applied Geosciences (UCAG) is thanked for the access to the Eugen Friedrich Stumpfl electron microprobe laboratory. Field work and preliminary investigations were supported by Russian Foundation of Basic Research (RFBR) grant No. 16-05-00508-a. We are very grateful to John Bowles and two anonymous referees for constructive comments that improved the manuscript. Many thanks are due to the editorial staff of Minerals and to the guest editor Maria Economou-Eliopoulos.

Author Contributions: Federica Zaccarini wrote the paper and analyzed the minerals by electron microprobe. Evgeny Pushkarev collected the samples and provided the geological and field information as well as the access to the Russian bibliography. Giorgio Garuti contributed to the elaboration and interpretation of the data and to the final revision of the manuscript. Igor Kazakov collected the samples and provided the information about the studied deposits.

Conflicts of Interest: The authors have no conflict of interest to declare.

\section{Appendix A}

Table A1. Representative electron microprobe analyses (wt \%) of chromite from chromitites of Alapaevsk.

\begin{tabular}{|c|c|c|c|c|c|c|c|c|c|c|c|c|}
\hline Sample & $\mathrm{Cr}_{2} \mathrm{O}_{3}$ & $\mathrm{Al}_{2} \mathrm{O}_{3}$ & $\mathrm{Fe}_{2} \mathrm{O}_{3}$ & $\mathrm{MgO}$ & $\mathrm{FeO}$ & $\mathrm{TiO}_{2}$ & $\mathrm{~V}_{2} \mathrm{O}_{3}$ & $\mathrm{NiO}$ & $\mathrm{ZnO}$ & $\mathrm{MnO}$ & $\mathrm{SiO}_{2}$ & Total \\
\hline \multicolumn{13}{|c|}{ Eastern Block } \\
\hline \multicolumn{13}{|c|}{ Bakanov Kluch } \\
\hline PE1870an1 & 59.35 & 10.08 & 4.01 & 12.81 & 14.21 & 0.19 & 0.00 & 0.00 & 0.00 & 0.25 & 0.00 & 100.89 \\
\hline PE1870an2 & 58.57 & 9.73 & 5.11 & 12.83 & 14.03 & 0.13 & 0.00 & 0.00 & 0.00 & 0.29 & 0.05 & 100.75 \\
\hline PE1870an3 & 59.16 & 9.74 & 4.18 & 12.69 & 14.41 & 0.16 & 0.02 & 0.00 & 0.00 & 0.18 & 0.09 & 100.63 \\
\hline PE1870an4 & 58.13 & 9.60 & 4.46 & 12.95 & 13.43 & 0.19 & 0.02 & 0.00 & 0.05 & 0.16 & 0.05 & 99.05 \\
\hline PE1870an5 & 57.56 & 9.61 & 5.49 & 13.15 & 13.13 & 0.10 & 0.00 & 0.01 & 0.00 & 0.20 & 0.07 & 99.31 \\
\hline PE1870an6 & 58.50 & 9.46 & 5.25 & 13.78 & 12.21 & 0.14 & 0.00 & 0.00 & 0.00 & 0.18 & 0.01 & 99.53 \\
\hline PE1870an7 & 57.26 & 9.79 & 5.66 & 13.37 & 12.93 & 0.22 & 0.00 & 0.04 & 0.00 & 0.20 & 0.04 & 99.51 \\
\hline PE1870an8 & 58.52 & 9.36 & 4.95 & 12.75 & 13.80 & 0.13 & 0.00 & 0.06 & 0.00 & 0.24 & 0.05 & 99.87 \\
\hline PE1870an9 & 57.75 & 9.52 & 6.00 & 13.58 & 12.49 & 0.12 & 0.00 & 0.03 & 0.03 & 0.19 & 0.01 & 99.72 \\
\hline PE1870an10 & 56.93 & 9.60 & 5.64 & 12.68 & 13.63 & 0.12 & 0.03 & 0.01 & 0.05 & 0.25 & 0.04 & 98.99 \\
\hline PE1871an1 & 54.93 & 9.39 & 8.09 & 10.95 & 16.75 & 0.17 & 0.07 & 0.02 & 0.00 & 0.26 & 0.00 & 100.65 \\
\hline PE1871an2 & 54.39 & 9.47 & 7.47 & 10.76 & 16.82 & 0.23 & 0.06 & 0.04 & 0.00 & 0.20 & 0.03 & 99.46 \\
\hline PE1871an3 & 54.63 & 9.62 & 7.98 & 10.95 & 16.89 & 0.23 & 0.06 & 0.07 & 0.04 & 0.15 & 0.03 & 100.65 \\
\hline PE1871an4 & 54.54 & 9.07 & 8.03 & 9.90 & 18.32 & 0.27 & 0.08 & 0.03 & 0.00 & 0.30 & 0.00 & 100.55 \\
\hline PE1871an5 & 54.61 & 9.33 & 7.86 & 9.44 & 19.34 & 0.27 & 0.05 & 0.03 & 0.00 & 0.23 & 0.00 & 101.16 \\
\hline PE1871an6 & 54.49 & 9.05 & 8.30 & 9.55 & 19.12 & 0.28 & 0.04 & 0.06 & 0.10 & 0.24 & 0.06 & 101.28 \\
\hline PE1871an7 & 54.14 & 9.52 & 8.06 & 10.62 & 16.98 & 0.16 & 0.04 & 0.05 & 0.10 & 0.24 & 0.02 & 99.93 \\
\hline PE1871an8 & 56.16 & 8.76 & 7.80 & 10.46 & 17.56 & 0.17 & 0.03 & 0.00 & 0.08 & 0.27 & 0.01 & 101.31 \\
\hline PE1871an9 & 54.61 & 9.49 & 8.21 & 10.48 & 17.95 & 0.36 & 0.06 & 0.08 & 0.00 & 0.25 & 0.04 & 101.52 \\
\hline PE1871an10 & 53.49 & 9.24 & 8.73 & 10.52 & 16.96 & 0.18 & 0.03 & 0.00 & 0.07 & 0.28 & 0.00 & 99.52 \\
\hline
\end{tabular}


Table A1. Cont.

\begin{tabular}{|c|c|c|c|c|c|c|c|c|c|c|c|c|}
\hline Sample & $\mathrm{Cr}_{2} \mathrm{O}_{3}$ & $\mathrm{Al}_{2} \mathrm{O}_{3}$ & $\mathrm{Fe}_{2} \mathrm{O}_{3}$ & $\mathrm{MgO}$ & $\mathrm{FeO}$ & $\mathrm{TiO}_{2}$ & $\mathrm{~V}_{2} \mathrm{O}_{3}$ & $\mathrm{NiO}$ & $\mathrm{ZnO}$ & $\mathrm{MnO}$ & $\mathrm{SiO}_{2}$ & Total \\
\hline \multicolumn{13}{|c|}{ Kurmanovskoe } \\
\hline PE1852an1 & 56.01 & 11.16 & 5.34 & 12.24 & 15.02 & 0.17 & 0.04 & 0.06 & 0.11 & 0.20 & 0.06 & 100.41 \\
\hline PE1852an2 & 56.18 & 11.50 & 4.94 & 12.22 & 15.13 & 0.15 & 0.03 & 0.05 & 0.06 & 0.18 & 0.02 & 100.46 \\
\hline PE1852an3 & 56.26 & 11.27 & 5.39 & 12.49 & 14.62 & 0.07 & 0.03 & 0.08 & 0.04 & 0.22 & 0.05 & 100.52 \\
\hline PE1852an4 & 55.28 & 10.44 & 6.62 & 11.50 & 15.91 & 0.16 & 0.06 & 0.08 & 0.01 & 0.32 & 0.02 & 100.40 \\
\hline PE1852an5 & 56.82 & 11.32 & 4.61 & 12.25 & 15.34 & 0.19 & 0.06 & 0.04 & 0.05 & 0.22 & 0.09 & 100.98 \\
\hline PE1852an6 & 55.93 & 11.25 & 5.60 & 12.24 & 14.98 & 0.17 & 0.03 & 0.06 & 0.11 & 0.23 & 0.00 & 100.60 \\
\hline PE1852an8 & 56.59 & 11.05 & 4.83 & 11.98 & 15.46 & 0.14 & 0.08 & 0.08 & 0.11 & 0.15 & 0.06 & 100.54 \\
\hline PE1852an9 & 56.47 & 11.27 & 5.14 & 12.51 & 14.58 & 0.13 & 0.08 & 0.06 & 0.10 & 0.20 & 0.01 & 100.54 \\
\hline PE1852an10 & 56.55 & 11.41 & 5.19 & 12.59 & 14.60 & 0.13 & 0.01 & 0.05 & 0.04 & 0.23 & 0.02 & 100.82 \\
\hline PE1855-1an1 & 57.79 & 11.41 & 4.75 & 14.37 & 11.93 & 0.14 & 0.00 & 0.11 & 0.00 & 0.21 & 0.05 & 100.76 \\
\hline PE1855-1an2 & 56.19 & 11.76 & 5.54 & 14.63 & 11.35 & 0.15 & 0.03 & 0.13 & 0.00 & 0.17 & 0.05 & 100.00 \\
\hline PE1855-1an3 & 57.16 & 11.79 & 5.15 & 14.61 & 11.60 & 0.12 & 0.00 & 0.05 & 0.01 & 0.23 & 0.03 & 100.75 \\
\hline PE1855-1an4 & 56.81 & 11.48 & 5.39 & 14.37 & 11.61 & 0.16 & 0.02 & 0.06 & 0.16 & 0.22 & 0.00 & 100.28 \\
\hline PE1855-1an5 & 56.73 & 11.56 & 5.24 & 14.70 & 11.03 & 0.22 & 0.00 & 0.16 & 0.15 & 0.18 & 0.00 & 99.97 \\
\hline PE1855-1an6 & 56.57 & 11.63 & 5.42 & 14.60 & 11.42 & 0.16 & 0.04 & 0.01 & 0.07 & 0.18 & 0.01 & 100.09 \\
\hline PE1855-1an7 & 56.09 & 11.56 & 5.92 & 14.90 & 10.99 & 0.23 & 0.01 & 0.06 & 0.00 & 0.18 & 0.02 & 99.96 \\
\hline PE1855-1an8 & 57.86 & 11.51 & 4.59 & 14.48 & 11.95 & 0.20 & 0.03 & 0.02 & 0.02 & 0.18 & 0.03 & 100.86 \\
\hline PE1855-1an9 & 56.91 & 11.48 & 4.74 & 14.61 & 11.42 & 0.23 & 0.07 & 0.05 & 0.00 & 0.06 & 0.00 & 99.56 \\
\hline PE1855-1an10 & 56.19 & 11.69 & 5.48 & 14.80 & 10.90 & 0.21 & 0.05 & 0.08 & 0.13 & 0.19 & 0.00 & 99.71 \\
\hline PE1856an1 & 42.90 & 22.16 & 7.08 & 15.51 & 11.85 & 0.33 & 0.09 & 0.05 & 0.11 & 0.19 & 0.06 & 100.33 \\
\hline PE1856an2 & 43.28 & 22.33 & 6.63 & 15.68 & 11.62 & 0.30 & 0.05 & 0.07 & 0.00 & 0.18 & 0.03 & 100.17 \\
\hline PE1856an3 & 44.15 & 22.45 & 6.29 & 15.55 & 12.29 & 0.37 & 0.06 & 0.01 & 0.00 & 0.18 & 0.00 & 101.34 \\
\hline PE1856an4 & 44.43 & 22.22 & 6.09 & 15.47 & 12.31 & 0.31 & 0.06 & 0.04 & 0.02 & 0.12 & 0.03 & 101.09 \\
\hline PE1856an5 & 43.63 & 22.63 & 6.34 & 15.58 & 12.11 & 0.35 & 0.07 & 0.05 & 0.07 & 0.14 & 0.02 & 100.99 \\
\hline PE1856an6 & 43.20 & 22.78 & 6.81 & 15.76 & 11.90 & 0.37 & 0.13 & 0.10 & 0.00 & 0.23 & 0.02 & 101.30 \\
\hline PE1856an7 & 42.91 & 22.32 & 7.09 & 15.54 & 11.77 & 0.26 & 0.11 & 0.06 & 0.07 & 0.15 & 0.01 & 100.30 \\
\hline PE1856an8 & 44.96 & 21.39 & 6.42 & 15.10 & 12.51 & 0.28 & 0.02 & 0.09 & 0.03 & 0.17 & 0.00 & 100.97 \\
\hline PE1856an9 & 45.47 & 20.91 & 6.42 & 15.21 & 12.47 & 0.35 & 0.07 & 0.07 & 0.02 & 0.16 & 0.02 & 101.15 \\
\hline PE1856an10 & 45.41 & 20.87 & 6.35 & 14.87 & 12.74 & 0.32 & 0.05 & 0.08 & 0.11 & 0.24 & 0.01 & 101.05 \\
\hline \multicolumn{13}{|c|}{ Western Block } \\
\hline \multicolumn{13}{|c|}{ Lesnoe } \\
\hline PE1863an1 & 42.87 & 23.60 & 5.96 & 16.64 & 10.08 & 0.24 & 0.05 & 0.09 & 0.04 & 0.15 & 0.00 & 99.72 \\
\hline PE1863an2 & 42.94 & 24.09 & 5.36 & 16.23 & 10.86 & 0.22 & 0.03 & 0.13 & 0.00 & 0.17 & 0.00 & 100.04 \\
\hline PE1863an3 & 43.81 & 23.99 & 5.81 & 16.89 & 10.28 & 0.20 & 0.06 & 0.07 & 0.00 & 0.22 & 0.03 & 101.36 \\
\hline PE1863an4 & 43.18 & 23.88 & 5.87 & 16.51 & 10.49 & 0.23 & 0.04 & 0.08 & 0.15 & 0.21 & 0.02 & 100.66 \\
\hline PE1863an5 & 43.98 & 24.35 & 2.58 & 14.70 & 13.17 & 0.26 & 0.07 & 0.08 & 0.00 & 0.19 & 0.01 & 99.39 \\
\hline PE1863an6 & 43.54 & 24.07 & 4.73 & 16.19 & 11.12 & 0.26 & 0.05 & 0.02 & 0.07 & 0.10 & 0.00 & 100.14 \\
\hline PE1863an7 & 42.92 & 23.97 & 5.85 & 16.74 & 10.29 & 0.22 & 0.11 & 0.16 & 0.00 & 0.13 & 0.06 & 100.45 \\
\hline PE1863an8 & 43.39 & 23.92 & 5.00 & 16.19 & 10.97 & 0.28 & 0.03 & 0.12 & 0.05 & 0.21 & 0.04 & 100.18 \\
\hline PE1863an9 & 42.69 & 23.81 & 6.15 & 16.70 & 10.43 & 0.31 & 0.06 & 0.02 & 0.00 & 0.27 & 0.07 & 100.52 \\
\hline PE1863an10 & 44.23 & 24.10 & 3.60 & 15.54 & 12.15 & 0.26 & 0.07 & 0.08 & 0.00 & 0.15 & 0.03 & 100.20 \\
\hline \multicolumn{13}{|c|}{ 3-d Podyony Rudnik } \\
\hline PE1869an1 & 42.27 & 23.01 & 7.44 & 15.80 & 11.79 & 0.37 & 0.08 & 0.10 & 0.00 & 0.17 & 0.00 & 101.02 \\
\hline PE1869an2 & 41.54 & 23.13 & 7.34 & 15.61 & 11.74 & 0.36 & 0.02 & 0.06 & 0.13 & 0.16 & 0.00 & 100.10 \\
\hline PE1869an3 & 41.33 & 23.76 & 7.39 & 15.84 & 11.83 & 0.40 & 0.09 & 0.15 & 0.00 & 0.21 & 0.03 & 101.03 \\
\hline PE1869an4 & 41.05 & 23.22 & 7.38 & 15.64 & 11.70 & 0.40 & 0.05 & 0.09 & 0.00 & 0.16 & 0.01 & 99.69 \\
\hline PE1869an5 & 41.86 & 23.84 & 6.81 & 15.59 & 12.40 & 0.41 & 0.03 & 0.16 & 0.00 & 0.10 & 0.02 & 101.20 \\
\hline PE1869an6 & 41.67 & 23.57 & 7.07 & 15.55 & 12.15 & 0.38 & 0.07 & 0.08 & 0.11 & 0.15 & 0.00 & 100.80 \\
\hline PE1869an7 & 42.55 & 23.46 & 6.94 & 15.67 & 12.13 & 0.32 & 0.07 & 0.01 & 0.16 & 0.15 & 0.00 & 101.44 \\
\hline PE1869an8 & 42.34 & 23.34 & 6.79 & 15.60 & 12.33 & 0.31 & 0.12 & 0.01 & 0.00 & 0.20 & 0.10 & 101.14 \\
\hline PE1869an9 & 42.14 & 23.27 & 7.77 & 15.94 & 11.54 & 0.25 & 0.09 & 0.09 & 0.00 & 0.25 & 0.00 & 101.32 \\
\hline PE1869an10 & 41.43 & 23.08 & 7.61 & 15.63 & 11.73 & 0.40 & 0.06 & 0.04 & 0.22 & 0.17 & 0.00 & 100.38 \\
\hline \multicolumn{13}{|c|}{ Bol'shaya Kruglyshka } \\
\hline PE1862an1 & 50.10 & 17.87 & 4.56 & 15.14 & 11.77 & 0.33 & 0.08 & 0.03 & 0.00 & 0.17 & 0.00 & 100.04 \\
\hline PE1862an2 & 49.64 & 18.14 & 5.12 & 15.47 & 11.03 & 0.22 & 0.02 & 0.07 & 0.08 & 0.18 & 0.00 & 99.98 \\
\hline PE1862an3 & 50.09 & 18.31 & 4.86 & 15.48 & 11.34 & 0.18 & 0.14 & 0.02 & 0.00 & 0.19 & 0.00 & 100.60 \\
\hline PE1862an4 & 50.96 & 18.39 & 4.42 & 15.50 & 11.61 & 0.21 & 0.04 & 0.04 & 0.00 & 0.16 & 0.00 & 101.33 \\
\hline PE1862an5 & 50.53 & 18.47 & 4.36 & 15.48 & 11.53 & 0.26 & 0.10 & 0.06 & 0.03 & 0.17 & 0.00 & 100.99 \\
\hline PE1862an6 & 50.51 & 18.56 & 4.17 & 15.44 & 11.74 & 0.30 & 0.03 & 0.05 & 0.00 & 0.19 & 0.05 & 101.03 \\
\hline PE1862an7 & 50.78 & 18.23 & 4.79 & 15.73 & 11.29 & 0.33 & 0.01 & 0.05 & 0.04 & 0.18 & 0.00 & 101.42 \\
\hline PE1862an8 & 49.59 & 18.11 & 4.28 & 15.26 & 11.22 & 0.29 & 0.00 & 0.07 & 0.00 & 0.21 & 0.02 & 99.05 \\
\hline PE1862an9 & 50.19 & 18.19 & 4.13 & 15.21 & 11.69 & 0.30 & 0.08 & 0.07 & 0.00 & 0.21 & 0.04 & 100.11 \\
\hline PE1862an10 & 49.75 & 17.78 & 5.18 & 15.41 & 11.02 & 0.29 & 0.02 & 0.12 & 0.06 & 0.22 & 0.00 & 99.84 \\
\hline
\end{tabular}


Table A1. Cont.

\begin{tabular}{|c|c|c|c|c|c|c|c|c|c|c|c|c|}
\hline Sample & $\mathrm{Cr}_{2} \mathrm{O}_{3}$ & $\mathrm{Al}_{2} \mathrm{O}_{3}$ & $\mathrm{Fe}_{2} \mathrm{O}_{3}$ & $\mathrm{MgO}$ & $\mathrm{FeO}$ & $\mathrm{TiO}_{2}$ & $\mathrm{~V}_{2} \mathrm{O}_{3}$ & $\mathrm{NiO}$ & $\mathrm{ZnO}$ & $\mathrm{MnO}$ & $\mathrm{SiO}_{2}$ & Total \\
\hline \multicolumn{13}{|c|}{ Krest } \\
\hline PE1859an1 & 41.08 & 24.76 & 6.32 & 14.79 & 13.49 & 0.22 & 0.10 & 0.08 & 0.00 & 0.23 & 0.00 & 101.07 \\
\hline PE1859an2 & 39.91 & 25.05 & 7.02 & 15.13 & 12.87 & 0.16 & 0.07 & 0.00 & 0.00 & 0.22 & 0.03 & 100.47 \\
\hline PE1859an3 & 40.75 & 24.34 & 6.89 & 15.16 & 12.52 & 0.18 & 0.00 & 0.07 & 0.00 & 0.22 & 0.00 & 100.12 \\
\hline PE1859an4 & 41.40 & 24.01 & 6.44 & 14.44 & 13.99 & 0.20 & 0.02 & 0.05 & 0.00 & 0.15 & 0.08 & 100.78 \\
\hline PE1859an5 & 40.97 & 24.42 & 6.49 & 14.86 & 13.14 & 0.24 & 0.04 & 0.10 & 0.10 & 0.18 & 0.03 & 100.54 \\
\hline PE1859an6 & 41.49 & 24.52 & 6.24 & 14.63 & 13.76 & 0.19 & 0.07 & 0.04 & 0.05 & 0.16 & 0.01 & 101.15 \\
\hline PE1859an7 & 39.13 & 18.69 & 8.22 & 12.47 & 18.20 & 0.13 & 0.03 & 0.00 & 0.01 & 0.48 & 2.23 & 99.59 \\
\hline PE1859an8 & 40.16 & 24.50 & 7.02 & 15.24 & 12.29 & 0.17 & 0.09 & 0.03 & 0.06 & 0.20 & 0.00 & 99.76 \\
\hline PE1859an9 & 40.56 & 24.60 & 7.29 & 15.41 & 12.26 & 0.15 & 0.07 & 0.09 & 0.07 & 0.21 & 0.00 & 100.71 \\
\hline PE1859an10 & 41.14 & 24.11 & 6.61 & 14.96 & 12.70 & 0.14 & 0.09 & 0.09 & 0.18 & 0.15 & 0.02 & 100.20 \\
\hline PE1860an1 & 44.20 & 22.10 & 6.16 & 15.84 & 11.15 & 0.26 & 0.08 & 0.09 & 0.06 & 0.23 & 0.00 & 100.15 \\
\hline PE1860an2 & 44.74 & 21.91 & 5.78 & 15.62 & 11.57 & 0.28 & 0.04 & 0.13 & 0.00 & 0.19 & 0.01 & 100.27 \\
\hline PE1860an3 & 44.19 & 21.75 & 6.20 & 15.56 & 11.40 & 0.20 & 0.07 & 0.07 & 0.01 & 0.18 & 0.00 & 99.62 \\
\hline PE1860an4 & 44.39 & 21.07 & 5.83 & 15.20 & 11.89 & 0.40 & 0.02 & 0.10 & 0.00 & 0.18 & 0.03 & 99.11 \\
\hline PE1860an5 & 45.43 & 21.78 & 5.17 & 15.16 & 12.51 & 0.32 & 0.10 & 0.10 & 0.00 & 0.13 & 0.00 & 100.71 \\
\hline PE1860an6 & 45.34 & 21.32 & 5.28 & 15.08 & 12.51 & 0.42 & 0.05 & 0.04 & 0.00 & 0.19 & 0.00 & 100.22 \\
\hline PE1860an7 & 45.69 & 20.70 & 5.88 & 15.15 & 12.02 & 0.33 & 0.10 & 0.12 & 0.06 & 0.25 & 0.00 & 100.31 \\
\hline PE1860an8 & 45.14 & 20.99 & 5.57 & 15.21 & 11.99 & 0.36 & 0.10 & 0.12 & 0.01 & 0.20 & 0.04 & 99.73 \\
\hline PE1860an9 & 45.19 & 20.95 & 5.38 & 15.15 & 11.97 & 0.34 & 0.08 & 0.05 & 0.00 & 0.15 & 0.00 & 99.27 \\
\hline PE1860an10 & 44.12 & 21.81 & 5.60 & 15.38 & 11.88 & 0.38 & 0.06 & 0.09 & 0.00 & 0.19 & 0.05 & 99.56 \\
\hline PE1861an1 & 43.30 & 22.44 & 6.51 & 15.41 & 11.99 & 0.25 & 0.07 & 0.07 & 0.00 & 0.16 & 0.00 & 100.20 \\
\hline PE1861an2 & 44.06 & 22.25 & 6.36 & 15.62 & 11.87 & 0.36 & 0.06 & 0.08 & 0.14 & 0.19 & 0.03 & 101.02 \\
\hline PE1861an3 & 43.47 & 22.36 & 6.70 & 15.65 & 11.70 & 0.28 & 0.05 & 0.04 & 0.01 & 0.20 & 0.00 & 100.43 \\
\hline PE1861an4 & 43.65 & 22.28 & 5.81 & 15.19 & 12.20 & 0.26 & 0.10 & 0.08 & 0.00 & 0.18 & 0.04 & 99.78 \\
\hline PE1861an5 & 43.16 & 23.01 & 5.70 & 15.48 & 12.07 & 0.28 & 0.10 & 0.01 & 0.11 & 0.19 & 0.10 & 100.21 \\
\hline PE1861an6 & 43.85 & 23.08 & 6.09 & 15.70 & 11.91 & 0.18 & 0.10 & 0.08 & 0.06 & 0.12 & 0.03 & 101.19 \\
\hline PE1861an7 & 43.39 & 22.60 & 6.86 & 15.51 & 11.96 & 0.20 & 0.07 & 0.09 & 0.00 & 0.21 & 0.00 & 100.87 \\
\hline PE1861an8 & 44.03 & 22.10 & 6.73 & 15.60 & 11.85 & 0.26 & 0.05 & 0.12 & 0.00 & 0.17 & 0.01 & 100.92 \\
\hline PE1861an9 & 43.68 & 22.22 & 6.96 & 15.58 & 11.83 & 0.25 & 0.08 & 0.12 & 0.06 & 0.23 & 0.04 & 101.04 \\
\hline PE1861an10 & 44.58 & 22.28 & 5.89 & 15.31 & 12.54 & 0.32 & 0.06 & 0.07 & 0.00 & 0.17 & 0.02 & 101.25 \\
\hline
\end{tabular}

Table A2. Representative electron microprobe analyses (wt \%) of olivine from chromitites of Alapaevsk.

\begin{tabular}{cccccccccc}
\hline Sample & $\mathbf{S i O}_{2}$ & $\mathbf{M g O}$ & $\mathbf{F e O}$ & $\mathbf{C r}_{2} \mathbf{O}_{3}$ & $\mathbf{M n O}$ & $\mathbf{N i O}$ & Total & Fo (\%) & Ca ppm \\
\hline & & \multicolumn{7}{c}{ Included in Chromite } \\
\hline PE1855-1an1 & 42.92 & 53.97 & 3.10 & 0.47 & 0.01 & 0.34 & 100.81 & 96.88 & 600 \\
PE1855-1an2 & 42.42 & 54.04 & 3.02 & 0.54 & 0.05 & 0.37 & 100.44 & 96.96 & 600 \\
PE1855-1an3 & 42.22 & 54.18 & 3.01 & 0.58 & 0.05 & 0.45 & 100.49 & 96.98 & 650 \\
PE1855-1an4 & 41.70 & 53.28 & 3.03 & 0.72 & 0.09 & 0.41 & 99.22 & 96.91 & 800 \\
PE1855-1an5 & 42.60 & 54.06 & 2.92 & 0.75 & 0.05 & 0.34 & 100.72 & 97.06 & 650 \\
PE1855-1an6 & 42.42 & 53.87 & 3.15 & 0.75 & 0.07 & 0.41 & 100.67 & 96.83 & 850 \\
PE1855-1an7 & 42.94 & 54.20 & 3.13 & 0.73 & 0.05 & 0.38 & 101.43 & 96.86 & 600 \\
PE1855-1an8 & 42.90 & 53.98 & 3.20 & 0.71 & 0.02 & 0.32 & 101.12 & 96.79 & 700 \\
\hline & & & & Interstitial & & & & \\
\hline PE1855-1an1 & 42.50 & 53.62 & 3.93 & 0.19 & 0.07 & 0.30 & 100.60 & 96.05 & 850 \\
PE1855-1an2 & 42.50 & 53.34 & 3.80 & 0.16 & 0.03 & 0.36 & 100.18 & 96.16 & 650 \\
PE1855-1an3 & 42.76 & 53.70 & 3.88 & 0.18 & 0.06 & 0.39 & 100.97 & 96.10 & 650 \\
PE1855-1an4 & 42.46 & 52.37 & 3.96 & 0.09 & 0.01 & 0.31 & 99.20 & 95.93 & 500 \\
PE1855-1an5 & 40.64 & 51.78 & 3.78 & 0.10 & 0.04 & 0.33 & 96.66 & 96.06 & 600 \\
PE1855-1an6 & 41.89 & 53.10 & 3.95 & 0.07 & 0.07 & 0.29 & 99.37 & 95.99 & 600 \\
PE1855-1an7 & 42.29 & 53.29 & 4.08 & 0.06 & 0.15 & 0.42 & 100.28 & 95.88 & 400 \\
PE1855-1an8 & 42.62 & 52.96 & 4.19 & 0.09 & 0.05 & 0.30 & 100.20 & 95.75 & 550 \\
\hline
\end{tabular}


Table A3. Representative electron microprobe analyses (wt \%) of clinopyroxene and amphibole included in chromite from chromitites of Alapaevsk.

\begin{tabular}{|c|c|c|c|c|c|c|c|c|c|c|c|c|}
\hline Sample & $\mathrm{SiO}_{2}$ & $\mathrm{Al}_{2} \mathrm{O}_{3}$ & $\mathrm{Cr}_{2} \mathrm{O}_{3}$ & $\mathrm{MgO}$ & $\mathrm{CaO}$ & $\mathrm{FeO}$ & $\mathrm{MnO}$ & $\mathrm{NiO}$ & $\mathrm{TiO}_{2}$ & $\mathrm{Na}_{2} \mathrm{O}$ & $\mathrm{K}_{2} \mathrm{O}$ & Total \\
\hline \multicolumn{13}{|c|}{ Clinopyroxene } \\
\hline PE1852-6 & 53.84 & 0.69 & 1.68 & 17.76 & 23.77 & 1.66 & 0.09 & 0.06 & 0.05 & 0.14 & 0.00 & 99.73 \\
\hline PE1852-4 & 54.10 & 0.62 & 1.77 & 17.29 & 24.07 & 1.53 & 0.04 & 0.00 & 0.03 & 0.17 & 0.01 & 99.62 \\
\hline PE1852-5 & 54.20 & 0.48 & 1.36 & 17.53 & 23.19 & 1.58 & 0.10 & 0.03 & 0.03 & 0.24 & 0.00 & 98.72 \\
\hline PE1870-1 & 54.48 & 0.46 & 1.69 & 17.64 & 23.70 & 1.08 & 0.09 & 0.01 & 0.07 & 0.29 & 0.01 & 99.52 \\
\hline PE1871-6 & 54.90 & 0.64 & 1.57 & 17.40 & 23.65 & 1.93 & 0.11 & 0.04 & 0.12 & 0.31 & 0.00 & 100.68 \\
\hline PE1870-3 & 55.15 & 0.62 & 1.91 & 17.74 & 23.68 & 1.16 & 0.02 & 0.05 & 0.09 & 0.40 & 0.00 & 100.80 \\
\hline PE1870-2 & 55.35 & 0.57 & 1.86 & 17.56 & 23.40 & 1.23 & 0.05 & 0.04 & 0.10 & 0.32 & 0.00 & 100.47 \\
\hline \multicolumn{13}{|c|}{ Amphibole } \\
\hline PE1871-1 & 44.40 & 9.81 & 3.25 & 19.65 & 12.34 & 2.78 & 0.09 & 0.05 & 0.41 & 3.33 & 0.66 & 96.76 \\
\hline PE1871-2 & 44.93 & 9.19 & 3.29 & 20.01 & 11.93 & 2.84 & 0.03 & 0.00 & 0.46 & 3.54 & 0.16 & 96.37 \\
\hline PE1871-3 & 45.41 & 9.67 & 3.11 & 19.73 & 11.99 & 2.71 & 0.08 & 0.04 & 0.39 & 3.60 & 0.16 & 96.88 \\
\hline PE1871-4 & 45.48 & 9.47 & 3.11 & 19.73 & 12.05 & 2.90 & 0.06 & 0.02 & 0.35 & 3.25 & 0.13 & 96.54 \\
\hline PE1869-12 & 45.84 & 10.01 & 2.30 & 19.31 & 11.47 & 3.03 & 0.13 & 0.05 & 2.04 & 2.70 & 0.02 & 96.88 \\
\hline PE1871-5 & 45.87 & 9.48 & 3.26 & 19.91 & 12.12 & 2.73 & 0.04 & 0.04 & 0.45 & 3.55 & 0.17 & 97.63 \\
\hline PE1869-9 & 46.15 & 9.74 & 2.41 & 18.77 & 11.46 & 2.97 & 0.10 & 0.04 & 1.84 & 3.73 & 0.07 & 97.28 \\
\hline PE1860-1 & 46.16 & 9.35 & 2.70 & 19.70 & 12.13 & 2.40 & 0.05 & 0.07 & 1.98 & 2.18 & 0.09 & 96.80 \\
\hline PE1869-3 & 46.55 & 9.86 & 2.41 & 19.33 & 11.61 & 2.96 & 0.04 & 0.08 & 1.80 & 2.39 & 0.01 & 97.04 \\
\hline PE1869-5 & 46.79 & 9.60 & 2.34 & 19.48 & 11.89 & 2.77 & 0.08 & 0.09 & 2.02 & 2.57 & 0.04 & 97.68 \\
\hline
\end{tabular}

Table A4. Representative electron microprobe analyses (wt \% and at.\%) of laurite from chromitites of Alapaevsk.

\begin{tabular}{|c|c|c|c|c|c|c|c|c|c|c|}
\hline Sample & $S$ & As & Os & Ir & $\mathbf{R u}$ & $\mathbf{R h}$ & $P d$ & $\mathrm{Fe}$ & $\mathrm{Cu}$ & Total \\
\hline \multicolumn{11}{|c|}{ wt $\%$} \\
\hline PE1855-1an1 & 34.44 & 1.15 & 22.13 & 0.60 & 36.83 & 1.78 & 1.67 & 0.15 & 1.40 & 100.15 \\
\hline PE1855-1an2 & 34.06 & 1.22 & 22.17 & 0.87 & 36.89 & 1.73 & 1.73 & 0.18 & 0.77 & 99.62 \\
\hline PE1855-1an3 & 34.42 & 1.22 & 22.76 & 0.40 & 37.37 & 1.69 & 1.77 & 0.24 & 0.66 & 100.54 \\
\hline PE1855-1an4 & 34.31 & 1.11 & 22.73 & 0.60 & 37.38 & 1.81 & 1.75 & 0.16 & 0.74 & 100.59 \\
\hline PE1855-1an5 & 34.78 & 1.29 & 18.26 & 1.84 & 38.65 & 2.10 & 1.85 & 0.15 & 0.26 & 99.19 \\
\hline PE1855-1an6 & 35.24 & 1.32 & 18.88 & 0.47 & 38.74 & 2.00 & 1.95 & 0.11 & 0.17 & 98.88 \\
\hline PE1855-1an7 & 33.42 & 1.03 & 21.03 & 0.76 & 38.40 & 2.01 & 2.04 & 0.14 & 0.03 & 98.87 \\
\hline PE1855-1an8 & 33.88 & 1.16 & 20.83 & 0.49 & 38.32 & 1.98 & 1.90 & 0.19 & 0.12 & 98.86 \\
\hline \multicolumn{11}{|c|}{ at. $\%$} \\
\hline PE1855-1an1 & 65.86 & 0.94 & 7.13 & 0.19 & 22.34 & 1.06 & 0.96 & 0.17 & 1.35 & \\
\hline PE1855-1an2 & 65.85 & 1.01 & 7.23 & 0.28 & 22.63 & 1.04 & 1.01 & 0.20 & 0.75 & \\
\hline PE1855-1an3 & 65.90 & 1.00 & 7.34 & 0.13 & 22.70 & 1.01 & 1.02 & 0.26 & 0.64 & \\
\hline PE1855-1an4 & 65.82 & 0.91 & 7.35 & 0.19 & 22.75 & 1.08 & 1.01 & 0.18 & 0.72 & \\
\hline PE1855-1an5 & 66.36 & 1.05 & 5.87 & 0.59 & 23.39 & 1.25 & 1.07 & 0.16 & 0.25 & \\
\hline PE1855-1an6 & 66.85 & 1.07 & 6.04 & 0.15 & 23.32 & 1.18 & 1.11 & 0.12 & 0.16 & \\
\hline PE1855-1an7 & 65.46 & 0.87 & 6.94 & 0.25 & 23.86 & 1.23 & 1.21 & 0.15 & 0.03 & \\
\hline PE1855-1an8 & 65.81 & 0.97 & 6.82 & 0.16 & 23.61 & 1.20 & 1.11 & 0.21 & 0.12 & \\
\hline
\end{tabular}

Table A5. Representative electron microprobe analyses (wt \%, at. \%, and apfu) of the NiFeP compound from chromitites of Alapaevsk.

\begin{tabular}{ccccc}
\hline Sample & P & Ni & Fe & Total \\
\hline \multicolumn{5}{c}{ wt \% } \\
\hline PE1870-1 & 10.16 & 88.05 & 1.30 & 99.51 \\
PE1870-2 & 10.15 & 89.12 & 1.26 & 100.53 \\
PE1870-3 & 10.17 & 89.29 & 1.19 & 100.64 \\
PE1870-4 & 10.15 & 88.14 & 1.19 & 99.48 \\
PE1870-5 & 9.41 & 89.89 & 1.18 & 100.47 \\
PE1870-6 & 10.13 & 88.33 & 1.23 & 99.69 \\
PE1870-7 & 10.09 & 88.17 & 1.24 & 99.49 \\
PE1870-8 & 10.18 & 89.45 & 1.18 & 100.81 \\
PE1870-9 & 10.11 & 88.57 & 1.18 & 99.86 \\
PE1870-10 & 10.19 & 89.17 & 1.13 & 100.49 \\
\hline
\end{tabular}


Table A5. Cont.

\begin{tabular}{ccccc}
\hline Sample & P & Ni & Fe & Total \\
\hline & \multicolumn{3}{c}{ at. $\%$} \\
PE1870-1 & 17.72 & 81.02 & 1.26 \\
PE1870-2 & 17.54 & 81.25 & 1.21 & \\
PE1870-3 & 17.55 & 81.31 & 1.14 \\
PE1870-5 & 17.71 & 81.14 & 1.15 \\
PE1870-6 & 16.37 & 82.50 & 1.13 \\
PE1870-7 & 17.64 & 81.17 & 1.19 \\
PE1870-8 & 17.61 & 81.20 & 1.20 \\
PE1870-9 & 17.54 & 81.33 & 1.13 \\
PE1870-10 & 17.59 & 81.28 & 1.14 \\
\hline PE1870-1 & 1.61 & 81.30 & 1.08 \\
PE1870-2 & 1.05 & 4.88 & \\
PE1870-3 & 1.05 & 4.88 & 0.07 \\
PE1870-4 & 1.06 & 4.87 & 0.07 \\
PE1870-5 & 0.98 & 4.95 & 0.07 \\
PE1870-6 & 1.06 & 4.87 & 0.07 \\
PE1870-7 & 1.06 & 4.87 & 0.07 \\
PE1870-8 & 1.05 & 4.88 & 0.07 \\
PE1870-9 & 1.06 & 4.88 & 0.07 \\
PE1870-10 & 1.06 & 4.88 & 0.07 & \\
\hline
\end{tabular}

\section{References}

1. Fershtater, G.B.; Montero, P.; Borodina, N.S.; Pushkarev, E.V.; Smirnov, V.N.; Bea, F. Uralian magmatism: An overview. Tectonophysics 1997, 276, 87-102. [CrossRef]

2. Savelieva, G.N.; Sharaskin, A.Y.; Saveliev, A.A.; Spadea, P.; Pertsev, A.N.; Babarina, I.I. Ophiolites and zoned mafic-ultramafic massifs of the Urals: A comparative analysis and some tectonic implications. Mountain building in the Uralides: Pangea to the present. AGU Geophys. Monogr. 2002, 132, 135-153.

3. Savelieva, G.N. Gabbro-Ultrabasite Assemblage of Ural Ophiolites and their Analogues in Recent Oceanic Crust; Nauka: Moscow, Russia, 1987; pp. 1-45. (In Russian)

4. Savelieva, G.N.; Saveliev, A.A. Relationship between peridotites and gabbroic sequence in the ophiolites of the Urals and the Lesser Caucasus. Ofioliti 1992, 17, 117-137.

5. Garuti, G.; Fershtater, G.; Bea, F.; Montero, P.; Pushkarev, E.V.; Zaccarini, F. Platinum-group element distribution in mafic-ultramafic complexes of Central and Southern Urals: Preliminary results. Tectonophysics 1997, 276, 181-194. [CrossRef]

6. Garuti, G.; Pushkarev, E.V.; Thalhammer, O.A.R.; Zaccarini, F. Chromitites of the Urals: Overview of chromite mineral chemistry and geo-tectonic setting (Part 1). Ofioliti 2012, 37, 27-53.

7. Koroteev, V.A.; de Boorder, H.; Necheukhin, V.M.; Sazonov, V.N. Geodynamic setting of the mineral deposits of the Urals. Tectonophysics 1997, 276, 291-300. [CrossRef]

8. Tatarinov, P.M.; Krasnovsky, G.M. Alapaevsky Intrusion of Ultramafic Rocks in the Urals and Related Chromite Deposits; Gosgeoltehisdat: Moscow-Leningrad, Russia, 1940; pp. 1-43. (In Russian)

9. Zaccarini, F.; Pushkarev, E.V.; Garuti, G. Platinum-group element mineralogy and geochemistry of chromitite of the Kluchevskoy ophiolite complex, central Urals (Russia). Ore Geol. Rev. 2008, 33, 20-30. [CrossRef]

10. The State Geological Map of Russian Federation. Scale 1:1000,000, 3rd ed.; Urals Series; O-41-Ekaterinburg; Explanatory Letter; VSEGEI; UGSE: St-Petersburg, Russia, 2011; p. 492.

11. Zoloev, K.K.; Chemyakin, V.I.; Shmaina, M.Y.; Medvedeva, T.N.; Mardirosyan, A.N.; Bashta, K.N. Bazhenovskoe Deposit of Chrysotile-Asbestos; Zoloev, K.K., Popov, B.A., Eds.; Nedra: Moscow, Russia, 1985; p. 271. (In Russian)

12. Petrov, G.A.; Ronkin, Y.L.; Maslov, A.V.; Lepikhina, O.P. Vendian and Silurian Ophiolite Formation Stages on the Eastern Slope of the Middle Urals. Dokl. Earth Sci. 2010, 432, 570-576. [CrossRef] 
13. Fershtater, G.B.; Borodina, N.S.; Rapoport, M.S.; Osipova, T.A. Orogenic Granitoid Magmatism of the Urals; IGG Ural Branch of RAS: Miass, Russia, 1994; p. 250. (In Russian)

14. Shilova, T.A. Chromspinel of the Alapaevsky Massif. In Mineralogical Digest No. 13: Mineralogy and Geochemistry of Ultramafites of the Urals; Uralian Scientific Center: Sverdlovsk, Russia, 1977; pp. 33-45. (In Russian)

15. Chashchukhin, I.S.; Votyakov, S.L.; Pushkarev, E.V.; Anikina, E.V.; Mironov, A.B.; Uimin, S.G. Oxythermobarometry of ultramafic rocks from the Ural Platiniferous Belt. Geochemistry 2002, 8, 846-863. (In Russian)

16. Perevozchikov, B.V.; Bulykin, L.D.; Popov, I.I.; Orfanitskiy, V.L.; Andreev, M.I.; Snachev, V.I.; Danilenko, S.A.; Cherkasov, V.I.; Chentsov, A.M.; Zharikova, L.N.; et al. The Registry of Chromite Deposits in Alpine-Type Ultramafites of the Urals; Perevozchikov, B.V., Ed.; KamaRICSDI: Perm, Russia, 2000; p. 474. (In Russian)

17. Chashchukhin, I.S.; Votyakov, S.L. Ultramafites of the Alapaevsky massif (Central Urals): Petrology, Geochemistry, Chromite resources. Litosphere 2012, 4, 140-157. (In Russian)

18. Thayer, T.P. Chromite segregations as petrogenetic indicators. Geol. Soc. S. Afr. Spec. Publ. 1970, 1, 380-390.

19. Arai, S. Chemistry of chromian spinel in volcanic rocks as a potential guide to magma chemistry. Miner. Mag. 1992, 56, 173-184. [CrossRef]

20. Ferraio, A.; Garuti, G. Platinum-Group Minerals in Chromite-Rich Horizons in the Niquelandia Complex, (Central Goias, Brazil); Prichard, H.M., Potts, P.J., Bowles, J.F.W., Cribb, S.J., Eds.; Springer: Rotterdam, The Netherlands, 1988; pp. 261-272.

21. Chashchukhin, I.S.; Votyakov, S.L.; Scianova, Y.V. Crystal Chemistry of Chrome Spinel and Oxygen Thermobarometry in Ultramafic Rocks; Russian Academy of Sciences, Ural Division, Institute of Geology and Geochemistry: Ekaterinburg, Russia, 2007; p. 312. (In Russian)

22. Melcher, F.; Grum, W.; Simon, G.; Thalhammer, T.V.; Stumpfl, F.E. Petrogenesis of the ophiolitic giant chromite deposits of Kempirsai, Kazakhstan: A study of solid and fluid inclusions in chromite. J. Petrol. 1997, 38, 1419-1438. [CrossRef]

23. Garuti, G.; Zaccarini, F.; Moloshag, V.; Alimov, V. Platinum-Group minerals as indicator of sulfur fugacity in ophiolitic upper mantle: An example from chromitites of the Ray-Iz ultramafic complex (Polar Urals, Russia). Can. Miner. 1999, 37, 1099-1115.

24. Anikina, Y.V.; Moloshag, V.P.; Alimov, V.Y.; Kononkova, N.N. Type chemistry of laurite from Polar Ural Alpine-type hyperbasites. Dokl. Russ. Acad. Sci. Earth Sci. Sect. 1996, 345, 410-412.

25. Britvin, S.N.; Kolomensky, V.D.; Boldyreva, M.M.; Bogdanova, A.N.; Krester, Y.L.; Boldyreva, O.N.; Rudashevsky, N.S. Nickelphosphide $(\mathrm{Ni}, \mathrm{Fe})_{3} \mathrm{P}-$ The nickel analog of schreibersite. Zap. Vserossi. Mineral. Obschch. 1999, 128, 64-72.

26. Skala, R.; Drabek, M. Nickelphosphide from the Vicenice octahedrite: Rietveld crystal structure refinement of a synthetic analogue. Miner. Mag. 2003, 67, 783-792. [CrossRef]

27. Pratesi, G.; Bindi, L.; Moggi-Cecchi, V. Icosahedral coordination of phosphorus in the crystal structure of melliniite, a new phosphide mineral from the Northwest Africa 1054 acapulcoite. Am. Miner. 2006, 91, 451-454. [CrossRef]

28. Britvin, S.N.; Murashko, M.N.; Vapnik, Y.; Polekhovsky, Y.S.; Krivovichev, S.V. CNMNC Newsletter No. 19, February 2014. Miner. Mag. 2014, 78, 165-170.

29. Uysal, I.; Zaccarini, F.; Garuti, G.; Meisel, T.; Tarkian, M.; Bernhardt, H.J.; Sadiklar, M.B. Ophiolitic chromitites from the Kahramanmaras area, southeastern Turkey: Their platinum group elements (PGE) geochemistry, mineralogy and Os-isotope signature. Ofioliti 2007, 32, 151-161.

30. Irvine, T.N. Chromian spinel as a petrogenetic indicator. Part I. Theory. Can. J. Earth Sci. 1965, 2, 648-672. [CrossRef]

31. Irvine, T.N. Chromian spinel as a petrogenetic indicator. Part II. Petrological applications. Can. J. Earth Sci. 1967, 4, 71-103. [CrossRef]

32. Dick, H.J.B.; Bullen, T. Chromian spinel as a petrogenetic indicator in abyssal and alpine-type peridotites and spatially associated lavas. Contrib. Miner. Petrol. 1984, 85, 54-76. [CrossRef]

33. Stowe, C.W. Compositions and tectonic settings of chromite deposits through time. Econ. Geol. 1994, 89, 528-546. [CrossRef]

34. Barnes, S.J.; Roeder, P.L. The range of spinel composition in terrestrial mafic and ultramafic rocks. Contrib. Miner. Petrol. 2001, 42, 2279-2302. [CrossRef] 
35. Kamenetsky, V.S.; Crawford, A.J.; Meffre, S. Factors controlling chemistry of magmatic spinel: An empirical study of associated olivine, Cr-spinel, and melt inclusions from primitive rocks. J. Petrol. 2001, 42, 655-671. [CrossRef]

36. Uysal, I.; Tarkian, M.; Sadiklar, M.B.; Zaccarini, F.; Meisel, T.; Garuti, G.; Heidrich, S. Petrology of Al- and Cr-rich ophiolitic chromitites from the Muğla, SW Turkey: Implications from composition of chromite, solid inclusions of platinum-group mineral, silicate, and base-metal mineral, and Os-isotope geochemistry. Contrib. Miner. Petrol. 2009, 158, 659-674. [CrossRef]

37. Llanes Castro, A.I.; Proenza, J.A.; Zaccarini, F.; Garuti, G.; Pacheco Sarlabous, M.S.C. Al- and Cr-rich chromitites from the Eastern Havana-Matanzas ophiolites (Western Cuba). Episodes 2015, 38, 334-343.

38. Leblanc, M.; Nicolas, A. Ophiolitic chromitites. Int. Geol. Rev. 1992, 34, 653-686. [CrossRef]

39. Zhou, M.-F.; Bai, W.-J. Chromite deposits in China and their origin. Miner. Depos. 1992, 27, $192-199$. [CrossRef]

40. Economou-Eliopoulos, M. Platinum-group element (PGE) distribution in chromite ores from ophiolite complexes of Greece: Implications for chromite exploration. Ofioliti 1993, 18, 83-97.

41. Leblanc, M. Chromitite and ultramafic rock compositional zoning through a Paleotransform fault, Poum, New Caledonia. Econ. Geol. 1995, 90, 2028-2039. [CrossRef]

42. Proenza, J.A.; Gervilla, F.; Melgarejo, J.C.; Bodinier, J.L. Al and Cr rich chromitites from the mayari-Baracoa Ophiolitic Belt, (eastern Cuba): Consequence of interaction between volatile-rich melts and peridotite in suprasubduction mantle. Econ. Geol. 1999, 94, 547-566. [CrossRef]

43. Kocks, H.; Melcher, F.; Meisel, T.; Burgath, K.P. Diverse contributing sources to chromite petrogenesis in the Shebenik Ophiolitic Complex, Albania: Evidence from new PGE- and Os-isotope data. Miner. Petrol. 2007, 91, 139-170. [CrossRef]

44. Grammatikopoulos, T.; Kapsiotis, A.; Tsikouras, B.; Hatzipanagiotou, K.; Zaccarini, F.; Garuti, G. Spinel composition, PGE geochemistry and mineralogy of the chromitites from the Vourinos ophiolite complex, northwestern Greece. Can. Miner. 2011, 49, 1571-1598. [CrossRef]

45. Zaccarini, F.; Garuti, G.; Proenza, J.A.; Campos, L.; Thalhammer, O.A.R.; Aiglsperger, T.; Lewis, J. Chromite and platinum-group-elements mineralization in the Santa Elena ophiolitic ultramafic nappe (Costa Rica): Geodynamic implications. Geol. Acta 2011, 9, 407-423.

46. Kapsiotis, A. Genesis of chromitites from Korydallos, Pindos Ophiolite Complex, Greece, based on spinel chemistry and PGE-mineralogy. J. Geosci. 2013, 58, 49-69. [CrossRef]

47. Ismail, S.A.; Kettanah, Y.A.; Chalabi, S.N.; Ahmed, A.H.; Arai, S. Petrogenesis and PGE distribution in the Al- and Cr-rich chromitites of the Qalander ophiolite, northeastern Iraq: Implications for the tectonic environment of the Iraqi Zagros Suture Zone. Lithos 2014, 202, 21-36. [CrossRef]

48. Miura, M.; Arai, S.; Ahmed, A.H.; Mizukami, T.; Okuno, M.; Yamamoto, S. Podiform chromitite classification revisited: A comparison of discordant and concordant chromitite pods from Wadi Hilti, northern Oman ophiolite. J. Asian Earth Sci. 2012, 59, 52-61. [CrossRef]

49. Miura, M.; Arai, S.; Ahmed, A.H.; Tamura, A. Formation of discordant chromitite as the initiation of sub-arc mantle process: Observations from northern Oman ophiolite. J. Miner. Petrol. Sci. 2014, 109, 38-43. [CrossRef]

50. Zaccarini, F.; Idrus, A.; Garuti, G. Chromite Composition and Accessory Minerals in Chromitites from Sulawesi, Indonesia: Their Genetic Significance. Minerals 2016, 6, 46. [CrossRef]

51. Li, C.; Thakurta, J.; Ripley, E.M. Low-Ca contents and kink-banded textures are not unique to mantle olivine: Evidence from the Duke Island Complex, Alaska. Miner. Petrol. 2012, 104, 147-153. [CrossRef]

52. Arai, S. Dunite-harzburgite-chromitite complexes as refractory residue in the Sangun-Yamaguchi zone, Western Japan. J. Petrol. 1980, 21, 141-165.

53. Lago, B.; Rabinowicz, M.; Nicolas, A. Podiform chromite ore bodies: A genetic model. J. Petrol. 1982, 23, 103-125. [CrossRef]

54. Arai, S.; Yurimoto, H. Podiform chromitites of the Tari-Misaka ultramafic complex, Southwest Japan, as mantle-melt interaction products. Econ. Geol. 1994, 89, 1279-1288. [CrossRef]

55. Zhou, M.F.; Robinson, P.T. High-Cr and high-Al podiform chromitites, Western China: Relationships to partial melting and melt/rock reaction in the upper mantle. Int. Geol. Rev. 1994, 36, 678-686. [CrossRef]

56. Zhou, M.F.; Robinson, P.T.; Bai, W.J. Formation of podiform chromites by melt-rock interaction in the upper mantle. Miner. Depos. 1994, 29, 98-101. [CrossRef] 
57. Zhou, M.F.; Robinson, P.T.; Malpas, J.; Zijin, L. Podiform chromites in the Luobusa Ophiolite (Southern Tibet): Implications for melt-rock interaction and chromite segregation in the upper mantle. J. Petrol. 1996, 37, 3-21. [CrossRef]

58. Arai, S. Control of wall-rock composition on the formation of podiform chromitites as a result of magma/peridotite interaction. Res. Geol. 1997, 47, 177-187.

59. Johan, Z.; Dunlop, H.; Le Bel, L.; Robert, J.L.; Volfinger, M. Origin of chromite deposits in ophiolitic complexes: Evidence for a volatile and sodium-rich reducing fluid phase. Fortschr. Miner. 1983, 61, 105-107.

60. Ballhaus, C. Origin of podiform chromite deposits by magma mingling. Earth Planet. Sci. Lett. 1998, 156, 185-193. [CrossRef]

61. Matveev, S.; Ballhaus, C. Role of water in the origin of podiform chromitite deposits. Earth Planet. Sci. Lett. 2002, 203, 235-243. [CrossRef]

62. Baumgartner, R.J.; Zaccarini, F.; Garuti, G.; Thalhammer, O.A.R. Mineralogical and geochemical investigation of layered chromitites from the Bracco-Gabbro complex, Ligurian ophiolite, Italy. Contrib. Miner. Petrol. 2013, 165, 477-493. [CrossRef]

63. Britvin, S.N.; Rudashevskii, N.S.; Krivovichev, S.V.; Burns, P.C.; Polekhovsky, Y.S. Allabogdanite, $(\mathrm{Fe}, \mathrm{Ni})_{2} \mathrm{P}$, a new mineral from the Onello meteorite: The occurrence and crystal structure. Am. Miner. 2002, 87, 1245-1249. [CrossRef]

64. Britvin, S.N.; Vapnik, Y.; Polekhovsky, Y.S.; Krivovichev, S.V. CNMNC Newsletter No. 15, February 2013. Miner. Mag. 2013, 77, 1-12.

65. Buseck, P.R. Phosphide from meteorites: Barringerite, a new iron-nickel mineral. Science 1969, 165, $169-171$. [CrossRef] [PubMed]

(C) 2016 by the authors; licensee MDPI, Basel, Switzerland. This article is an open access article distributed under the terms and conditions of the Creative Commons Attribution (CC-BY) license (http://creativecommons.org/licenses/by/4.0/). 